NBER WORKING PAPER SERIES

\title{
THE LABOR MARKET IMPACT OF IMMIGRATION IN WESTERN GERMANY IN THE 1990'S
}

\author{
Francesco D'Amuri \\ Gianmarco I.P. Ottaviano \\ Giovanni Peri \\ Working Paper 13851 \\ http://www.nber.org/papers/w13851
}

\author{
NATIONAL BUREAU OF ECONOMIC RESEARCH \\ 1050 Massachusetts Avenue \\ Cambridge, MA 02138 \\ March 2008
}

We thank Mark Bryan, Joan Esteban, Marco Francesconi, Tim Hatton, Arianna Miglietta, Cheti Nicoletti, Thomas Siedler and seminar participants at Fondazione Mattei, ISER, IZA and University of Hamburg for very helpful comments and suggestions. D'Amuri is grateful for support from the Economic and Social Research Council. Ottaviano gratefully acknowledges the financial support from the Volkswagen Foundation as part of the Study Group on Migration and Integration, "Diversity, Integration and the Economy". Peri gratefully acknowledges the John D. and Catherine T. MacArthur Foundation for generously funding his migration-related research. The opinions expressed in this paper do not necessarily reflect those of the Bank of Italy, its staff, or the National Bureau of Economic Research.

NBER working papers are circulated for discussion and comment purposes. They have not been peerreviewed or been subject to the review by the NBER Board of Directors that accompanies official NBER publications.

(C) 2008 by Francesco D'Amuri, Gianmarco I.P. Ottaviano, and Giovanni Peri. All rights reserved. Short sections of text, not to exceed two paragraphs, may be quoted without explicit permission provided that full credit, including $\odot$ notice, is given to the source. 
The Labor Market Impact of Immigration in Western Germany in the 1990's

Francesco D'Amuri, Gianmarco I.P. Ottaviano, and Giovanni Peri

NBER Working Paper No. 13851

March 2008, Revised February 2009

JEL No. E24,F22,J31,J61

\begin{abstract}
$\underline{\text { ABSTRACT }}$
We adopt a general equilibrium approach in order to measure the effects of recent immigration on the Western German labor market, looking at both wage and employment effects. Using the Regional File of the IAB Employment Subsample for the period 1987-2001, we find that the substantial immigration of the 1990's had no adverse effects on native wages and employment levels. It had instead adverse employment and wage effects on previous waves of immigrants. This stems from the fact that, after controlling for education and experience levels, native and migrant workers appear to be imperfect substitutes whereas new and old immigrants exhibit perfect substitutability. Our analysis suggests that if the German labor market were as 'flexible' as the UK labor market, it would be more efficient in dealing with the effects of immigration.,
\end{abstract}

Francesco D'Amuri

Bank of Italy,

Via Nazionale 91,

00184, Rome

ITALY

and ISER, University of Essex

francesco.damuri@bancaditalia.it

Gianmarco I.P. Ottaviano

University of Bologna

Dip Scienze Economiche

Strada Maggiore 45, 40125 Bologna

ITALY

ottavian@economia.unibo.it
Giovanni Peri

Department of Economics

University of California, Davis

One Shields Avenue

Davis, CA 95616

and NBER

gperi@ucdavis.edu 


\section{Introduction}

Within Europe, Germany hosts the largest number of foreign individuals-workers with foreign origin have represented more than $10 \%$ of the total German labor force since the late 1990 's. ${ }^{1}$ The socioeconomic worries produced by rising immigration led the German government to introduce a selective immigration system based on quotas, which was passed by the parliament but declared void by the Federal Constitutional Court in 2002. In 2004 a comprehensive Immigration Act introduced the possibility for immigrant workers to change their temporary residence permit to an unlimited one after having paid at least 60 monthly contributions to social security, provided that they pass a German language proficiency test. ${ }^{2}$

German labor market institutions are characterized by generous unemployment benefits and wage rigidities, which increase the potential for negative employment consequences due to immigration: newcomers and, in general, immigrants are more likely to stay jobless as wages do not adjust to shocks. Such institutional features, specific to Germany, prevent the possibility of analyzing the labor market impact of immigrants using a straightforward extension of recent analyses that focus on the United States (Borjas, 2003; Ottaviano and Peri, 2008), the United Kingdom (Manacorda et al., 2006) or Israel (Friedberg, 2001). Those countries all have more flexible labor markets, lower hiring and firing costs and less generous unemployment insurance vis-a-vis Germany. Two considerations, however, emerge from those studies that should inform the analysis of the effects of immigration in Germany. First, the effects of immigration depend on the composition of native and immigrant workers, in terms of education and experience, and not just on the overall inflow of immigrants. In the case of Germany, this is stressed by De New and Zimmermann (1994) who analyze the wage effects of immigration to Germany for the 1984-1989 period. Segmenting the national labor market across industries, these authors find that immigrant workers substitute for unskilled natives and complement skilled natives. Second, and less obvious, is that even after controlling for education and experience, native and immigrant workers may not be perfectly substitutable.

Certainly the labor market effects of immigration are sensitive to the institutional setup. ${ }^{3}$ For instance, the importance of labor market institutions in mediating the effects of immigration on wages and employment is stressed by Angrist and Kugler (2003). For a panel of European Economic Area countries for 1983-1999, the authors show that labor market rigidities cause adverse employment effects. This finding echoes the results of Pischke and Velling (1997) who, using data

\footnotetext{
${ }^{1}$ Authors' calculation using the IAB data introduced in section 4.

${ }^{2}$ See Zimmermann et al. (2007) for an outline and an economic evaluation of the norms contained in the Immigration Act.

${ }^{3}$ For a theoretical model in which labor market institutions prevent wages from falling to their market clearing level when immigration occurs, see Schmidt et al. (1994).
} 
on 167 German regions for the 1985-1989 period, show some evidence of the displacement of the native workforce by immigration. More recently, Glitz (2006) analyzes the specific issue of the impact of ethnic German immigration on the relative skill-specific employment and wage rates of the resident population in different geographic areas between 1996 and 2001. He finds evidence of adverse employment effects but no detrimental effects on average wages.

The present paper investigates the interactions between immigration, employment and wages in Western Germany using the more structural labor market equilibrium approach recently employed in several national studies (Aydemir and Borjas, 2007; Borjas, 2003; Manacorda et al., 2006; Ottaviano and Peri, 2008). This approach is based on the aforementioned idea that the average and distributive effects of immigration depend on the exact composition of native and immigrant workers in terms of education and experience. This requires a careful estimation of the substitution elasticities between different groups of workers because the marginal productivity (wages) of each group depends on the supply of workers in the other groups. In particular, we allow native and migrant workers to be imperfect substitutes in production, even if sharing the same education and experience levels as in Ottaviano and Peri (2008) and Manacorda et al. (2006). In addition, and in contrast to those papers, we also allow for a further degree of imperfect substitutability between 'old' and 'new' immigrant workers, where 'new' (old) migrants are defined as those who are observed working in Germany for five years or less (strictly more than five years). Moreover, to account for the institutional frictions existing in the German labor market, we investigate not only the wage effects of immigration but also the employment effects, since in an imperfect labor market employment would be an important margin of adjustment to shocks in the presence of rigid wages.

Our results provide a full picture of the adjustment of the Western German labor market to migration in the period from 1987 to 2001. In terms of employment, we find negative effects of new immigrants on previous immigrants, while we do not find evidence of such effects on native workers. Our estimates suggest that, for any ten new immigrants in the German labor market, three to four old immigrants are driven out of employment, whereas no native is affected. Reinforcing the evidence of stronger competition between new and old immigrants rather than between immigrants and native workers, we also find an imperfect degree of substitutability between natives and new immigrants, whereas new and old immigrants are close to perfect substitutes. In particular, we estimate a significant elasticity of substitution between natives and immigrants of around 20 (close to what Ottaviano and Peri (2008) and Card (2009) find between native and immigrants in the US) and an elasticity of substitution between new and old immigrants of around 60 and not significantly different from the one implied by perfect substitutability. 
In terms of wage effects, our estimated elasticities imply that over the period 1992-2001 new immigrants to Western Germany reduced the average wages of long-term immigrants by 0.5\%, with highly educated long-term immigrants losing around 1.1\% of their wages. Approximately half of the negative wage effect on the highly educated was due to immigration from Eastern Germany. As for the effects of new immigration on natives, there is essentially a null average effect: negative on highly educated $(-1 \%)$ and close to zero or positive on the less educated and on those with vocational education. We conclude the paper with some simple calculations in which we use our estimated elasticities to discuss the aggregate costs of immigration in the presence of wage rigidities compared to the case of fully flexible wages and no negative employment effects.

The rest of the paper is organized as follows: section 2 briefly outlines the relevant features of the history of immigration in Germany and reviews the relevant related literature. Section 3 describes the theoretical framework behind our evaluation of the wage and employment effects of immigration. Section 4 presents the data used for our econometric analysis, describes the refinements aimed at making the data best suited to analyze the labor market effects of immigrants and presents summary statistics. Results from the econometric analysis of the employment effects of immigration are presented in section 5, which also discusses important empirical issues and estimates the substitutability between natives and migrant workers across skill groups, using these estimates to calculate the equilibrium effects of immigration on employment and wages. Section 6 discusses the implications of our findings in terms of the aggregate costs of immigration with or without wage rigidity. Section 7 concludes.

\section{Immigration to Western Germany and Related Literature}

After World War II, Western Germany experienced two large flows of immigrants. First, during the 1950's and 1960's, the country experienced a large inflow of Turks and Southern European (mostly unskilled) workers with no German background. Then, during the early 1990's, so-called ethnic Germans (individuals with German ancestry returning from abroad), and Eastern Germans moved "en masse" to Western Germany. ${ }^{4}$

The first inflow of foreign workers began in the mid-1950s. In that period the recruitment of guest workers coming mainly from South and South-East European countries started. Guest workers were poorly skilled workers recruited for a limited period of one to two years and then required to return to their countries of origin. The inflow of foreigners steadily increased during the Cold War period until the 1973 oil crisis, when the economic downturn induced the government to

\footnotetext{
${ }^{4}$ For a detailed description of immigration flows in Germany and for a survey of empirical results of its labor market impact see Zimmermann et al. (2007).
} 
ban the recruitment of workers from abroad. According to the German Federal Statistical Office, in that year foreign population accounted for around 6.4\% of Western Germany's total population. Notwithstanding the ban on the recruitment of guest workers, the foreign population remained constant, thanks to family reunifications for those workers who managed to settle permanently in Germany. ${ }^{5}$

After the end of the Cold War, Germany resumed the temporary migration policy, mainly attracting workers from Central and Eastern Europe. Over the eleven years following the reunification in 1990, more than 2 million Germans moved from the East to the West (Statistisches-BundesamtDeutschland, 2006a). Another parallel immigration flow of ethnic Germans involved 2.8 million people between 1988 and 2001 (Statistisches-Bundesamt-Deutschland (2006b)). Ethnic Germans are a peculiar group of immigrants because they have German nationality but, since they lived abroad for a long period (often more than one generation), their knowledge of the German language and of German habits is not comparable to that of natives. For example, according to Federal Administration Office data reported in Bauer et al. (2005), 62.6\% of the ethnic Germans applying for admission to Germany between July 1996 and April 1999 failed the German language test. In the words of Zimmermann (1999), "ethnic Germans are basically facing the same difficulties with social and economic integration as foreigners". Overall, in 20017.3 million foreigners accounted for $8.8 \%$ of the total German population.

The present paper is related in its approach to the recent literature that analyzes the impact of immigration on the labor market outcomes of natives of different skills (education and experience) popularized by Borjas (2003), Borjas and Katz (2007) and Ottaviano and Peri (2008) for the US and applied by Manacorda et al. (2006) to the analysis of immigration to the UK. Bonin (2005) applies a skill-based analysis of immigration to the German labor market. His approach, however, is a reduced-form one. He identifies the partial effect of immigration on wages of each skill group but, since he does not specify a structure of labor demand and supply he cannot identify the total effects of immigration on wages and employment. Moreover, the analysis defines immigrants simply as foreign nationals in the IAB and therefore omits the very important inflow of Eastern Germans and Ethnic German immigrants.

Following the working paper version of the present paper (D'Amuri et al., 2008), other studies have analyzed the impact of immigration on the employment and wages of West Germans. Those studies have either used somewhat different data (such as the GSOEP used in Felbermayr et al. (2008)) or focused on somewhat different policy experiments (as Brucker and Jahn (2008)). While

\footnotetext{
${ }^{5}$ Even if guest workers were formally allowed to spend only a limited time period in Germany, this provision was not effectively enforced. Moreover, no recruitment halt was possible for foreign workers coming from European Community countries.
} 
generally confirming our results those studies provide interesting extensions, robustness checks and alternative policy analyses which complement the present article.

\section{Theoretical framework}

To analyze the wage and employment effects of immigration in Western Germany we use a framework similar to the one Ottaviano and Peri (2008) and Borjas (2003) adopted to analyze immigration to the US. Output is produced using a combination of physical capital and a labor composite of groups of workers differing in their education, age and national origins. The wage paid to each group is equal to its skill-specific marginal productivity.

To fit the significant flexibility of the US labor market, Ottaviano and Peri (2008) and Borjas (2003) assume that wages always adjust to clear the labor market so that the inflow of new immigrants is entirely absorbed by wage changes. In the context of the German labor market, however, an additional and potentially relevant margin of adjustment is constituted by changes in employment due to the presence of some degree of wage rigidity. For this reason, we augment the original setup of Ottaviano and Peri (2008); Borjas (2003) with elements used by Saint-Paul (1996), Acemoglu and Angrist (2001) as well as Angrist and Kugler (2003) to study the effects of labor market regulation.

\subsection{Production}

As in Ottaviano and Peri (2008) and Borjas (2003), firms employ labor and physical capital $(K)$ to produce a homogeneous final product, which is sold in a perfectly competitive market and is taken as numeraire good. Technology is such that physical capital and a labor composite are combined in a Cobb-Douglas production function to produce output under constant returns to scale. The labor composite is itself a CES aggregator of employees with different work experience nested within educational groups. We allow for further degrees of imperfect substitutability between natives and immigrants and also between old and new immigrants to Western Germany. The aggregate production function is:

$$
Y_{t}=A_{t} L_{t}^{\alpha} K_{t}^{1-\alpha}
$$

where the subscript $t$ indicates the time period, $Y_{t}$ is output, $A_{t}$ is total factor productivity (TFP), $K_{t}$ is physical capital, $L_{t}$ is the CES aggregator of different types of employees and $\alpha \in(0,1)$ is the income share of labor. The labor composite $L_{t}$ is in turn defined as:

$$
L_{t}=\left[\sum_{k=1}^{3} \theta_{k t} L_{k t}^{\frac{\delta-1}{\delta}}\right]^{\frac{\delta}{\delta-1}}
$$


where $L_{k t}$ is itself a CES aggregator of employees with educational level $k$ and $\theta_{k t}$ are educationspecific productivity levels standardized such that $\sum_{k} \theta_{k t}=1$. Workers are grouped in three educational levels, $k=1,2,3$, corresponding to workers with no vocational degree, workers with a vocational degree and workers with tertiary education. The parameter $\delta>1$ measures the elasticity of substitution among the three educational groups.

As in Card and Lemieux (2001), workers with the same education but different work experience are also considered as imperfect substitutes, with $L_{k t}$ defined as:

$$
L_{k t}=\left[\sum_{j=1}^{8} \theta_{k j} L_{k j t}^{\frac{\eta-1}{\eta}}\right]^{\frac{\eta}{\eta-1}}
$$

where $j=1,2, \ldots, 8$ is an index capturing five-year intervals of potential experience, spanning a minimum of 0 to a maximum of 40 years. The term $\eta>1$ measures the elasticity of substitution between workers with the same education but different potential experience and $\theta_{k j}$ are their education-experience-specific productivity levels, standardized such that $\sum_{j} \theta_{k j t}=1$. Following Ottaviano and Peri (2008), native and immigrant workers are allowed to be imperfect substitutes in production since the two groups may have different abilities and skills which affect their comparative advantages and hence their choices of occupation (Peri and Sparber (2009)). Consequently, $L_{k j t}$ is defined as:

$$
L_{k j t}=\left[\theta_{H k j t} H_{k j t}^{\frac{\sigma-1}{\sigma}}+\theta_{M k j t} M_{k j t}^{\frac{\sigma-1}{\sigma}}\right]^{\frac{\sigma}{\sigma-1}}
$$

where $H_{k j t}$ and $M_{k j t}$ denote, respectively, native ('Home') and immigrant ('Migrant') workers; $\sigma>1$ is their elasticity of substitution; $\theta_{H k j t}$ and $\theta_{M k j t}$ are their specific productivity levels, with $\theta_{H k j t}+\theta_{M k j t}=1$. Finally, we also allow $M_{k j t}$ to be a CES aggregator of old and new immigrants:

$$
M_{k j t}=\left[\theta_{k j t}^{O L D}\left(M_{k j t}^{O L D}\right)^{\frac{\lambda-1}{\lambda}}+\theta_{k j t}^{N E W}\left(M_{k j t}^{N E W}\right)^{\frac{\lambda-1}{\lambda}}\right]^{\frac{\lambda}{\lambda-1}}
$$

where $M_{k j t}^{O L D}\left(M_{k j t}^{N E W}\right)$ denotes migrants with education $k$ and experience $j$ who are observed working in Western Germany for five years or less (strictly more than five years). In (5) the

parameter $\lambda>1$ denotes their elasticity of substitution while $\theta_{k j t}^{O L D}$ and $\theta_{k j t}^{N E W}$ represent their specific productivity levels standardized so that $\theta_{k j t}^{O L D}+\theta_{k j t}^{N E W}=1$.

In all expressions, the relative efficiency parameters, $\theta$, and the total factor productivity, $A_{t}$, depend on technological factors only and are thus independent of the supply of migrant workers.

\subsection{Wage Rigidity}

We account for wage rigidities by assuming that the wage of natives with education $k$ and experience $j$ has to satisfy the following reduced-form constraint:

$$
H_{k j t}=\left[w_{H k j t}(1-r)\right]^{\xi_{H}} \bar{H}_{k j t}
$$


where $\bar{H}_{k j t}$ is the native labor force, $w_{H k j t}$ is the native wage rate, $\xi_{H}>0$ measures the elasticity of native employment with respect to wages, and $r \geq 0$ is the unemployment insurance replacement rate.

Expression (6) captures the fact that native employment and the uninsured portion of the wage they receive are linked. Hence a change in wages (produced by a change in the supply of some type of labor) may induce an employment response for natives. An analogous expression holds for old immigrants:

$$
M_{k j t}^{O L D}=\left[w_{M k j t}^{O L D}(1-r)\right]^{\xi_{M}} \bar{M}_{k j t}^{O L D}
$$

where $\xi_{M}>0$ measures the elasticity of immigrant employment with respect to their wage. The elasticities $\xi_{H}$ and $\xi_{M}$ are allowed to be different for natives and immigrants.

Whereas the native and old immigrant labor forces are static, the population of new immigrants is subject to exogenous shocks. In particular, since new immigrants appear in our dataset only upon finding their first job in Germany, we assume that the employment of new immigrants $M_{k j t}^{N E W}$ coincides with their level in the labor force $\bar{M}_{k j t}^{N E W}$. Accordingly, $M_{k j t}^{N E W}$ is exogenous whereas $H_{k j t}$ and $M_{k j t}^{O L D}$ are determined as wages adjust to the inflow of $M_{k j t}^{N E W}$.

The theoretical underpinnings of (6) and (7) are simply stated. If there was unemployment in a perfect labor market, unemployed workers would bid the wage down until labor demand met labor supply. In (6) and (7) that happens when $\xi=0$. Theories of unemployment suggest reasons why this mechanism fails to operate. Three main reasons have been highlighted in the literature (see, e.g., Romer (2001), for a survey). First, in efficiency-wage theories the equilibrium wage is above its market clearing rate because higher wages raise the productivity of labor. When, for instance, workers tend to shirk and monitoring is imperfect, unemployment allows firms to enforce workers' discipline. The resulting 'no-shirking condition' gives rise to a positive relation between employment and wages consistent with $\xi>0$ in (6) and (7). Second, whereas in efficiency-wage theories firms do not want to cut wages to prevent workers from shirking, in contracting theories firms would like to cut wages but they cannot, due to some explicit or implicit agreement with their workers. This happens, for example, in 'insider-outsider' models that distinguish between 'insider' workers, whose interests are taken into account at the time of bargaining, and 'outsider' workers, whose preferences are, instead, irrelevant. Greater insider power increases (outsider) unemployment by raising the contracted wage and forcing firms to move up their demand schedules. The resulting positive relation between wage and employment is again consistent with $\xi>0$ in (6) and (7). Third and last, relations like (6) and (7) can also be generated by the so-called flow approach to labor markets according to which, when confronted with the pronounced heterogeneity of workers and jobs, the idea that their matching up occurs through markets is inherently flawed. Workers and 
firms will meet, instead, through a complex process of search and matching. From this viewpoint, however, wages are not set according to Walrasian labor demand as in (8), (9), the reason being that search and matching implies that the value of a filled job deviates from the marginal productivity of labor.

\subsection{Labor Market Equilibrium}

In equilibrium wages and employment levels are such that firms maximize profits (i.e,. they are on their labor demand curves) and the two constraints (6) and (7) bind. The production function (1) can be used to calculate the demand for each type of labor at a given period $t$. Specifically, profit maximization requires that the natural logarithm of the wage of native workers with education $k$ and experience $j$ equals the natural logarithm of their marginal productivity in units of output:

$$
\begin{aligned}
\ln \left(w_{H k j t}\right)= & \ln \left(\alpha A_{t} \kappa_{t}^{1-\alpha}\right)+\frac{1}{\delta} \ln \left(L_{t}\right)+\ln \left(\theta_{k t}\right)-\left(\frac{1}{\delta}-\frac{1}{\eta}\right) \ln \left(L_{k t}\right)+\ln \left(\theta_{k j t}\right)-\left(\frac{1}{\eta}-\frac{1}{\sigma}\right) \ln \left(L_{k j t}\right) \\
& +\ln \left(\theta_{H k j t}\right)-\frac{1}{\sigma} \ln \left(H_{k j t}\right)
\end{aligned}
$$

where $\kappa_{t}=K_{t} / L_{t}$ is the capital-labor ratio. Similarly, the natural logarithm of the wage of old immigrants with education $k$ and experience $j$ is:

$$
\begin{aligned}
\ln \left(w_{M k j t}^{O L D}\right)= & \ln \left(\alpha A_{t} \kappa_{t}^{1-\alpha}\right)+\frac{1}{\delta} \ln \left(L_{t}\right)+\ln \left(\theta_{k t}\right)-\left(\frac{1}{\delta}-\frac{1}{\eta}\right) \ln \left(L_{k t}\right)+\ln \left(\theta_{k j t}\right)-\left(\frac{1}{\eta}-\frac{1}{\sigma}\right) \ln \left(L_{k j t}\right) \\
& +\ln \left(\theta_{M k j t}\right)-\left(\frac{1}{\sigma}-\frac{1}{\lambda}\right) \ln \left(M_{k j t}\right)+\ln \left(\theta_{k j t}^{O L D}\right)-\frac{1}{\lambda} \ln \left(M_{k j t}^{O L D}\right)
\end{aligned}
$$

Aggregating the marginal pricing conditions for each education-experience group implies the following relationship between the compensation going to the composite labor input $L_{k j t}$ and its supply:

$$
\begin{aligned}
\ln \left(\bar{W}_{k j t}\right)= & \ln \left(\alpha A_{t}^{\frac{1}{\alpha}} \kappa_{t}^{\frac{1-\alpha}{\alpha}}\right)+\frac{1}{\delta} \ln \left(L_{t}\right)+\ln \theta_{k t} \\
& -\left(\frac{1}{\delta}-\frac{1}{\eta}\right) \ln \left(L_{k t}\right)+\ln \theta_{k j}-\frac{1}{\eta} \ln \left(L_{k j t}\right)
\end{aligned}
$$

where $\bar{W}_{k j t}=w_{M k j t}\left(M_{k j t} / L_{k j t}\right)+w_{H k j t}\left(H_{k j t} / L_{k j t}\right)$ is the average wage paid to workers in the education-experience group $k, j$ and can be considered as the compensation to one unit of the composite input $N_{k j t}$.

Aggregating the production function one level further, together with marginal cost pricing, implies that the compensation going to the labor input $L_{k t}$ satisfies the following expression:

$$
\ln \left(\bar{W}_{k t}\right)=\ln \left(\alpha A_{t}^{\frac{1}{\alpha}} \kappa_{t}^{\frac{1-\alpha}{\alpha}}\right)+\frac{1}{\delta} \ln \left(L_{t}\right)+\ln \theta_{k t}-\frac{1}{\sigma} \ln \left(N_{k t}\right)
$$


where $\bar{W}_{k t}=\sum_{j}\left(\frac{L_{k j t}}{L_{k t}}\right) \bar{W}_{k j t}$ is the average wage in education group $k .^{6}$

In calculating the effects of new immigration on wages, we will take into account that physical capital adjusts to changes in the labor supply so as to keep its real rate of return constant. This is a reasonable assumption since Ortega and Peri (2009) recently found that within OECD countries physical capital fully adjusts to immigration within one year, in order to maintain constant returns to capital. This implies that in expressions (8) and (9), the capital-labor ratio $\kappa_{t}$ follows a trend determined only by the growth of total factor productivity $A_{t}$ so that the overall impact of new immigration on native and old immigrant wages can be obtained by computing the total changes of (8) and (9) with respect to the changes in the labor aggregates $\left(L_{t}, L_{k t}, L_{k j t}\right)$ induced by new immigrants. This yields the expressions (18) and (20) reported in Appendix A, which enables us to calculate the wage effects of new immigration once we know the corresponding employment responses (calculated as 19) and the estimates for $\delta, \eta, \sigma$ and $\lambda$ based on (8), (9), (10) and (11).

\section{Data and Empirical Implementation}

In this section we present our dataset, we discuss its pros and cons and we detail some procedures used to clean and refine the data in order to make them as representative as possible. We also present some summary statistics and preliminary evidence on immigration and on natives' and immigrants' employment and wages.

\subsection{The IAB Employment Subsample}

The data we employ are from the German Institute for Employment Research (IAB). ${ }^{7}$ The administrative dataset spans the period 1975-2001 and covers all employment spells subject to social security taxation and the unemployment spells during which the individual received unemployment benefits. The population includes workers and trainees liable to make social security contributions. The self-employed, civil servants and students enrolled in higher education are not included in the dataset. Hence the dataset is representative of people with a stable job who are not self-employed, and it excludes groups with high turnover and who are on the margins of the labor markets. According to Bender et al. (2000), in 1995 the IAB data cover nearly $79.4 \%$ of all employed individuals in Western Germany, but the coverage varies across occupations and industries (coverage levels are not declared). The data we use are an annual $2 \%$ random sample of the overall relevant population

\footnotetext{
${ }^{6}$ The weight for the wage of each group equals the size of the composite input for that education-experience cell, $L_{k j t}$, relative to the size of the composite input for the whole education group $L_{k t}$. This is measured by the share of group $k, j$ in educational group $k$.

${ }^{7}$ The interested reader can also refer to Bender et al. (2000) for a detailed description of the data.
} 
for a total of around 400,000 employment spells per year.

The IAB dataset is well suited for the analysis of labor market outcomes in the German labor market, especially for people with high attachment to the labor market such as male heads of households. It has been largely used to inquire into issues related to German wages and employment. One major advantage of this data is the very large, consistent and continuous coverage over time: it records more than 20 million employment spells between 1975 and 2001. For each employment spell, all the relevant information regarding the employees is collected by the employer and reported directly to the social security agencies. Measurement error is therefore kept to a minimum. The transmission of all the relevant information to the employment agency is mandatory, so that there are no issues arising from non-response. At the same time the sample is representative of the whole (social-security-paying) labor force each year in the sample. An alternative dataset reporting information on wages, employment and immigration status is the German Socioeconomic Panel Study (GSOEP) ${ }^{8}$. While that panel study has some desirable features, such as the identification of country of birth (which is better than nationality in identifying immigrants) and a complete history of employment which allows calculation of effective experience, it also has two serious problems, in our view. The first is that it is based on a much smaller sample so that in many education-experience cells (according to our definition) it contains very few observations or none at all, especially for immigrants. This makes it very hard to construct representative measures of wage and employment by cell. Second, it is a panel data set started in 1984 with infrequent refreshments (1994, 1998 and 2000). Hence the data (wages and employment) on new immigrants is only included infrequently. During the intermediate years only the sample weights are adjusted to reflect the changing population but no new information on flows and wages is used. Since our analysis focuses on new immigrants and on their effects on relative wages and employment, this seems a major limitation. Therefore we decided to use the IAB dataset and to address a series of issues by refining and cleaning the data (as described below). In the end we have an aggregate, representative dataset that we can compare to the GSOEP (see section 4.2 below) with a much larger number of observations in each cell. This allows more precise measures of cell employment and wages used in the regressions.

\subsection{Data refinements}

The IAB dataset has some limitations. We try to carefully address each one of them to produce a dataset that is as good and as representative as possible for our purposes. In Table 1 we compare systematically some summary statistics obtained from our refined dataset with summary statistics

\footnotetext{
${ }^{8}$ For a full description of this dataset see Haisken-DeNew and Frick (2005)
} 
from the GSOEP for years 1987, 1991 and 2001 which represent the initial, an intermediate and the final year for our empirical analysis. While, as stated above, the GSOEP dataset is also imperfect it is helpful to see some systematic differences between the two and whether they are likely to bias our results.

A first limitation of the IAB data is that there are no recall questions on the working history of each worker prior to the date of entry in the dataset. As a consequence it is not possible to reconstruct the exact work experience of an individual, and so we impute it. In so doing, we follow the standard assumption that potential experience is equal to the worker's age minus the typical age at which she is expected to have completed her education (Borjas (2003)) $)^{9}$. While this method can introduce some error, Table 1 shows the comparison of population mean and standard deviation of imputed experience (IAB) with actual experience from the GSOEP (worker history is available in these data). There is usually less than one year difference in the averages and standard deviations for both natives and immigrants.

A second and, for our purposes, more severe limitation of the IAB data is that for immigrants neither the place of birth, nor the year of arrival in Western Germany are recorded. What is available for each individual is the exact nationality at the country level. Since the focus of this paper is on immigration rather than nationality, this requires further assumptions about the link between the former and the latter. In particular, we assume that workers that declare at least once to be foreign nationals are immigrants. Hence, people who naturalize during the period under consideration (notice that since 2000 the naturalization laws have become less strict) are still considered immigrants. Also, there are very few people naturalized before 1975 . On the other hand, the presence of a large second generation of immigrants with foreign nationality may produce an over-count of the number of immigrants. However, since we identify most of our effects from the changes in a cohort of immigrants, the presence of a constant group of second generation immigrants will not affect the estimates much. Moreover, our main results are unaffected when we instrument total migrants' shares using only Germans who moved from the East to the West after reunification, a recent flow of migrants for which the second generation group should be negligible. Besides workers with foreign nationality we also identify two other groups as immigrants: German workers who migrated from the East to the West after reunification (and are recorded as Eastern German by the IAB); and Ethnic German workers, who primarily immigrated from Eastern Europe and who constitute a very large share of recent immigrant inflows. As they are an important group

\footnotetext{
${ }^{9}$ The age of entry in the labor force is assumed to be 16 for high school dropouts with no vocational education, 19 for high school dropouts with vocational education or high school graduates without vocational education, 21 for high school graduates with vocational education, 24 for those who completed non-university higher education and 25 for workers who hold a university degree.
} 
that would be missed by looking at the nationality variable only, we account for them using an external source of data. Our procedure (described in detail in Appendix B) accounts for the inflows of ethnic Germans across years and country of origin assuming that within year-of-arrival and country-of-origin their education and age characteristics are similar to those of the other foreign-born from that country. The procedure may systematically alter the education structure of ethnic immigrants if for each country of origin regular immigrants are systematically more educated than ethnic Germans. This is possible since it was easier for less educated ethnic Germans to enter Western Germany. We confirm in three different ways that this potential mis-classification does not alter our findings. First, we run some regressions using the "imputed" education of immigrants obtained from their occupation-industry rather than from their schooling. If ethnic Germans are systematically less educated they would choose appropriate occupations and the imputing of education should address this problem. Second, we specify some regressions omitting the ethnic Germans' imputation to see if it drives the results. Third, we compare the educational distribution of immigrants between our data and the GSOEP. Table 1 shows that our data in 2001 produce a lower share of highly educated than the GSOEP. This would argue against any upward bias introduced by imputing. While certainly imperfect, we think that our procedure uses the available data in its most efficient way and does not seem to introduce a systematic bias in the results.

After these imputations we compare the share and characteristics of immigrants (including ethnic and Eastern Germans) in the IAB and in the GSOEP (see Table 1). Notice again that their share in total employment is similar (in the IAB we have if anything a slight over-count) and their gender, experience and educational distribution are very close, except for a much larger share of highly educated immigrants in 2001 according to the GSOEP. As this over-representation of the highly educated in the GSOEP is also present for natives it may be worth inquiring as to the cause, but it should not affect the procedures by which we impute immigrants.

A third refinement on the data is that we impute the daily wage data which are right censored by the upper limit of the social insurance contribution in the IAB. Right censoring occurs in around $2 \%$ of the spells. Censored wages are imputed using the estimated wage values obtained from a Tobit regression model. This is run separately for each year and includes the following independent variables: experience, experience squared, educational attainment, nationality, 17 sector dummies and 131 occupational dummies. Table 1 shows that the average wages in IAB are 10 to $15 \%$ higher for all groups relative to those in GSOEP, and their standard deviation is similar in the two groups.

A fourth refinement that we use in some regressions is to allow for educational downgrading. Immigrants, in fact, may accept jobs requiring a lower level of qualification than they have(Dustmann et al., 2007). In this case the reported level of education can be a poor indicator of the labor market 
position of immigrants, decreasing the precision of our stratification of workers across educationexperience cells. In order to address this problem, we group native and immigrant workers according to reported education as well as according to 'adjusted' educational levels. In particular, similar to Card (2001) and Card (2007), for each available year we run an ordered Probit regression for the native population with the reported level of education as the dependent variable and 17 sector plus 131 occupational dummies as independent variables. This regression estimates, for each worker, the probability of having each of the possible educational levels, given his position in the labor market. Out of sample predictions are obtained for all immigrant workers and for those natives who failed to report their educational level and should otherwise have been dropped from the sample. The corresponding densities, averaged across individuals in each year, are then used to calculate weighted employment and wage levels for our education-experience cells. While this correction should improve the homogeneity of workers' skills within the group, it is more subject to endogeneity bias as immigrants may adjust their occupation in Germany according to sector demand. For this reason, we only use it as a robustness check.

Finally, to obtain a representative sample of days worked in a year in the economy (not just a total employment count), in each relevant year we include men aged 17 to 64 who were working and receiving salary income on the 1st of July. ${ }^{10}$ The probability of working that day (and hence being in the sample) is proportional to the number of days worked in a year. Hence the probability works as a weight for each worker by days worked. The number of hours worked per day is another possible dimension to look at. Unfortunately, daily hours worked are not reported in this dataset. Nevertheless, EULFS data ${ }^{11}$ show that part-time employment accounts for a small share of total male employment in Germany, and its yearly variations are controlled for by the year dummies which we employ in our regressions. Nominal gross wages are all converted to 2000 Euros using the CPI-based deflator across years.

Our analysis focuses on the period 1987-2001. During this period an extremely large influx of immigrants (including Eastern Germans and ethnic Germans) substantially increased the share of non-Western German workers in the Western German labor force. Figure 1 reports the share of immigrants in the labor force as obtained from the refined IAB dataset, showing that it climbed from about $9 \%$ in 1987 to $14 \%$ in 2001 . The time period analyzed is particularly interesting for the analysis of the labor market impact of immigration: the inflow of immigrant workers was very large and in large part supply-driven (due to the fall of the Iron Curtain and the uncertainty following the aftermath of socialism in the countries of origin). Indeed, the large and sudden rise in the share

\footnotetext{
${ }^{10}$ As a robustness check, we also run all the regressions on the sample including both men and women.

${ }^{11}$ According to data reported in ILO (2007), the share of part-time workers in total employment in Germany has never been above 5 percent in the period 1991-2001.
} 
of immigrant workers, mostly due to push factors, makes this somewhat of a 'natural experiment'one which is well suited to assessing the impact of immigration on incumbent workers. ${ }^{12}$

\subsection{Stylized Facts and Descriptive Statistics}

Let us first describe simple aggregate evidence that points to the existence of significant differences in labor market performances between immigrants and natives. Figure 2 shows the evolution of the share of individuals receiving unemployment benefits relative to the total workforce, calculated separately for native Germans and immigrant workers for the period 1987-2001 from the IAB dataset. Two tendencies emerge. First, the rates for native German and immigrant workers are quite stable and fairly similar over the period 1987-1991, a period of relatively small inflows of immigrants. Second, beginning in 1991 the unemployment rate for immigrants increases significantly. For native Germans it increases much less, opening a gap that is quite persistent, though it narrows toward the end of the 1990's.

Table 2 reports, for selected years, the shares of immigrants in each of the education-experience cells used in the regressions. As always we reclassify the ethnic Germans as immigrants following the procedure described in the previous section and in Table 2 we show the percentage of nonWestern Germans both from foreign countries and from Eastern Germany. The share of the non-native workforce in total employment more than doubles in many cells between 1987 and 2001. Large inflows of immigrants took place in all education groups. Interestingly, while the Eastern German immigrants were over-represented among those of intermediate and high levels of educations, the immigrants from foreign countries were proportionally more numerous among the less educated group. Merging the two groups we obtain a group of immigrants which is fairly balanced among the three education groups. This is part of the reason why we do not find large relative wage shifts as a consequence of immigration.

To summarize, a preliminary look at the data suggests that there has been a substantial increase in the number of immigrant workers over the period of observation. While this increase has been quite evenly distributed across educational levels, the labor market performance of migrants has been worse compared to natives in terms of unemployment rates. This may suggest stronger competition of new immigrants with existing foreign-born workers in terms of employment. The following econometric analysis will investigate this hypothesis.

\footnotetext{
${ }^{12}$ Bauer et al. (2005), p. 217, provide descriptive evidence on the independence between the growth of foreign employment and the business cycle after the fall of the Iron Curtain.
} 


\section{$5 \quad$ Employment and Wage Effects}

The aim of the present section is to estimate the employment and wage responses of old immigrants and natives to the arrival of new immigrants, building on the theoretical framework detailed in section 3. We proceed in three steps. First, we estimate the effects of new immigration on the employment levels of native and old immigrant workers in the same skill group. Second, from the production function (1) we derive empirical specifications that allow us to estimate the various elasticities of substitution. In particular, we estimate the elasticity of substitution between natives and immigrants for given education and experience $(\sigma)$ as well as the elasticity between new and long-term immigrants for given education and experience $(\lambda)$. We then estimate the elasticity of substitution between educational levels $(\delta)$ as well as between experience levels for a given educational level $(\eta)$. Finally, once we have the estimated employment effects and elasticities of substitution, we use expressions (18) and (20) to compute the impact of the inflow of new immigrants on the wages of natives and old immigrants with different levels of education.

\subsection{Empirical Issues: Demand Shocks and Estimation Bias}

Before implementing the empirical specifications let us note that a common feature throughout the estimation procedure is that we consider changes in the employment of new immigrants as a labor market supply shock. In particular, when we estimate either the employment response of previous immigrants and natives, or the response of wages we rely on the assumption that the inflow of new immigrants is an exogenous supply shock. Therefore, (i) we can consider the employment response of natives as actually caused by the immigrant inflow and (ii) we can consider the wage responses as identifying the relative wage elasticity (elasticity of substitution) of labor demand. This may look like a strong assumption. After all we are essentially regressing (total) employment on immigration and wages on immigration and we may be identifying a parameter that mixes demand and supply changes. We think, however, that considering the estimated parameters in section 5.2 as genuine measures of the employment response, and those in section 5.3 as demand elasticities, is reasonable in light of the following three facts.

First, and least important, the entire literature which analyzes the national effects of immigration using this framework makes the same simple assumption that immigrants are an exogenous shock to the national labor supply (e.g. Borjas (2003); Borjas and Katz (2007); Ottaviano and Peri (2008)).

Second, while the overall flow of immigrants can be driven by demand pull, since we use variations and control for year, education and experience fixed effects we rely on the differential change of immigrant flows within an education-experience cell. This is likely to be driven mostly 
by demographic factors in the sending country (i.e., the size of a cohort relative to the others). Moreover, in all the elasticity regressions we use relative native-immigrant wages and relative native-immigrant employment ${ }^{13}$ so that any demand shock specific to education and experience groups will affect both natives and immigrants and would be cancelled when taking the ratio.

Third, and most important, in our estimates we also rely on an IV strategy based on a quasinatural experiment: the German reunification. In the aftermath of the reunification (1991) a large increase in Eastern German immigrants was observed which was simply due to the fact that migrating became a possibility. Hence, treating the inflow of Eastern Germans as a pure supply shock, post-1991, we perform several 2SLS estimations using that flow as an instrument for all new immigrants. Notice, finally, that if some demand shock, not controlled for, were still driving part of the correlation (between relative wages and relative supply of new immigrants) it would bias our estimates of the inverse elasticity of substitution towards 0 . Hence, particularly for the elasticity of substitution between native and immigrants, our estimates (around 0.04-0.05) could be a lower bound of the actual inverse elasticity, which would imply even lower substitutability between native and immigrants and certainly less than perfect substitutability.

\subsection{Employment Effects}

We first estimate the response of long-term immigrants' and natives' employment levels to the inflow of new immigrants in the same education-experience cells. Such an adjustment in employment (if it takes place) reveals the presence of wage rigidities and frictions that must be accounted for when analyzing the effect of immigration on wages.

\subsubsection{New and Long-term Immigrants}

Following a standard specification (see, e.g., Card (2007)), we assess the possible employment effects of new immigrants on long-term immigrants by regressing the increase in the total employment of immigrants (new plus long-term) in skill cell $k, j$, denoted as $\Delta M_{k j t}$, on the increase in employment due to new immigrants in the same cell, denoted as $\Delta M_{k j t}^{N E W}$. To obtain scale-independent changes we standardized both changes by the initial level of employment of immigrants in the skill group $M_{k j t-1}$. We consider as "new immigrants" those in the country five years or less and as "old immigrants" those in the country more than five years. In particular, we estimate the following specification:

$$
\frac{\Delta M_{k j t}}{M_{k j t-1}}=D_{k}+D_{j}+D_{t}+\gamma \frac{\Delta M_{k j t}^{N E W}}{M_{k j t-1}}+u_{k j t}
$$

\footnotetext{
${ }^{13}$ Or new/old immigrant wage and employment ratios.
} 
In expression (12) $D_{k}, D_{j}$ and $D_{t}$ are, respectively, education, experience and year fixed effects included in order to control for systematic differences in employment growth across education groups, experience groups and years. The term $u_{k j t}$ is a zero mean cell-specific random shock. Since the data used are yearly data, the coefficient $\gamma$ captures the short-run employment effect of recent immigration on the employment of previous immigrants. A value of $\gamma=1$ implies that an inflow of new immigrants with education $k$ and experience $j$ equal to $1 \%$ of the initial employment in that cell is associated with an increase in total immigrant employment within the same education-experience cell of $1 \%$. In this case, new immigrants add to previous employment without crowding out any old immigrants so there is no response of employment of old immigrants to inflows of new immigrants. In contrast, an estimated value of $\gamma<1$ implies that new immigrants crowd out the employment of old immigrants inducing a decrease in their employment.

Table 3 reports the estimates of the coefficient $\gamma$ from estimating equation (12). Different columns show estimates from different specifications. Column (1) reports the basic specification: Least Squares estimates, weighting each cell by the total employment in it, spanning the period 1987-2001, including males only in the sample and considering the sum of Eastern Germans, foreign nationals and ethnic Germans born abroad as immigrants. Specification (2) omits the ethnic German imputation, specification (3) includes both men and women in the sample. In specification (4) we assign workers to education cells according to their imputed education (computed as described in section 4.2). Specifications (5) and (6) restrict data to subsamples that omit the very early years (pre-unification) or recent years (post-monetary union). Finally the last two columns (7) and (8) estimate the coefficient $\gamma$ using 2SLS with the flow of Eastern Germans as an instrument for total immigrants. Most of the point-estimates of $\gamma$ are between 0.6 and 0.7 , and in all cases the hypothesis that the coefficient is one can be rejected at standard confidence levels against the alternative $\gamma<1$. This constitutes evidence that new immigrants are crowding out long-term immigrants. The estimates of $\gamma$ are the lowest when using the 2SLS method, implying the largest crowding out. Notice that the first stage reveals that the inflow of Eastern Germans is a powerful instrument (F-test above 200, well above the lower bound of 10 suggested by the literature on weak instruments (Bound et al., 1995; Stock and Yogo, 2002)). In the post-1991 period, the inflow of Eastern Germans represented a very sizeable group among new immigrants. A formal test cannot reject the hypothesis that WLS and 2SLS estimates are identical. This suggests that, if we believe that the inflow of Eastern Germans was mainly a supply shock, the largest part of the immigration fluctuations are supply-driven once we control for year and cell fixed effects. Our estimates for $\gamma$ imply that, on average, when 10 new immigrants join the German labor force, 3 to 4 old immigrants lose their jobs. 


\subsubsection{Immigrants and Natives}

To estimate the impact of immigrants on the employment of native workers, we use an empirical specification similar to (12) and based on the theoretical model in section 3 . In particular we estimate the coefficient $\rho$ in the following regression:

$$
\frac{\Delta E M P L_{k j t}}{E M P L_{k j t-1}}=D_{k}+D_{j}+D_{t}+\rho \frac{\Delta M_{k j t}}{E M P L_{k j t-1}}+u_{k j t}
$$

Using the notation from the model, the variable $E M P L_{k j t-1}=M_{k j t-1}+H_{k j t-1}$ is total employment (immigrants plus natives) with education $k$ and experience $j$ at time $t-1$ and $\triangle E M P L_{k j t}=$ $\left[\left(M_{k j t}+H_{k j t}\right)-\left(M_{k j t-1}+H_{k j t-1}\right)\right]$ is its variation from $t-1$ to $t$. The variables $D_{k}, D_{j}$ and $D_{t}$ are the usual education, experience and time dummies and $u_{k j t}$ is a zero mean cell-specific random shock. The parameter $\rho$ captures the impact of immigration on total employment. If it is smaller than 1 , it implies that new immigrants crowd natives out. If it equals 1 , new immigrants have no impact on native employment.

Table 4 presents the estimates of the coefficient $\rho$. The different specifications across columns of Table 4 mirror those of Table 3. In this case, however, while the estimates are quite imprecise, they are all around, and in fact above, one. We can never reject the hypothesis of $\rho=1$ at any significance level and even the point estimates seem to rule out the possibility of crowding out. The 2SLS estimates, while they are very imprecise in part because the inflow of Eastern Germans is not as good an instrument for the change in employment of total immigrants as it was for new immigrants, confirm this result. All in all, the estimates in Table 4 do not provide any support for the idea that changes in immigrant employment crowd out employment of native Germans. These results seem to preclude the presence of adverse employment effects of new immigrants on natives even in the short run (as we use yearly observations). To further check this result, we run another regression (not in the Table) in which we stratify native and migrant workers according to their education only, instead of using the finer stratification of education-experience cells. If Western German employers valued differently the work experience acquired inside and outside Western Germany, our labor market segmentation along education and experience levels could fail to appropriately identify groups of workers competing for the same jobs. Also, if there are employment effects spilling across experience groups one would not capture them with the above regression. Hence, we group workers according to their education level only and we run the following regression:

$$
\frac{\Delta E M P L_{k t}}{E M P L_{k t-1}}=D_{k}+\operatorname{Trend}_{k}+\rho_{E D U} \frac{\Delta M_{k t}}{M_{k t-1}}+u_{k t}
$$

where $E M P L_{k t-1}=\sum_{j} E M P L_{k j t-1}, M_{k t}=\sum_{j} M_{k j t-1}$ and $u_{k t}$ is a zero mean education-specific shock. This regression controls for education fixed effects $\left(D_{k}\right)$ as well as education-specific trends 
$\left(\operatorname{Trend}_{k}\right)$ and is estimated using the usual samples. The point estimate of $\rho_{E D U}$ in the basic specification is 1.48 (standard error 0.51 ) so that we cannot reject $\rho_{E D U}=1$. The limit of this regression is that it is run on 45 observations only.

All in all, the results from employment regressions imply that we can rule out the presence of adverse effects of new immigration on the employment levels of native workers, while long-term immigrants seem negatively affected by newcomers ${ }^{14}$. Moreover, since the time horizon is one year (short-run) and labor markets were somewhat rigid in Germany during the period the lack of an effect on natives seems to imply a strong segmentation of the labor market, possibly due to differences between immigrants ('outsiders') and natives ('insiders').

\subsection{Elasticities of Substitution}

We now turn to the estimation of the elasticities of substitution. The empirical evidence discussed so far highlights the presence of different employment effects of recent immigration on the German labor market: significant negative effects on old immigrants and no effects on native employment. These differences seem to confirm that immigrant workers compete more between themselves than with natives, even within groups of similar observable skills. Indeed, if the only relevant variables for identifying similar workers were their education and experience, we would not observe different employment effects. In line with this consideration, the theoretical framework outlined in section 3 allows for imperfect substitutability in production between natives and immigrants as well as between old and recent immigrants. It also suggests how to estimate the elasticities of substitution between these groups of workers.

\subsubsection{New and Long-term Immigrants}

In order to estimate the elasticity of substitution between immigrants, we use the logarithmic wages given by expression (9) for old immigrants and its analogue for new ones. Taking the ratio within education-experience cells and controlling for the relative demand term $\ln \left(\theta_{k j t}^{O L D} / \theta_{k j t}^{N E W}\right)$ using fixed education $\left(D_{k}\right)$, experience $\left(D_{j}\right)$ and year $\left(D_{t}\right)$ effects we estimate the following specification:

$$
\ln \left(\frac{w_{M k j t}^{O L D}}{w_{M k j t}^{N E W}}\right)=D_{k}+D_{j}+D_{t}-\frac{1}{\lambda} \ln \left(\frac{M_{k j t}^{O L D}}{M_{k j t}^{N E W}}\right)+u_{k j t}
$$

Essentially we allow the relative new/old immigrant productivity to depend systematically on their education, age and on the year. We interpret the remaining within-cell variation of migrants

\footnotetext{
${ }^{14}$ These results are consistent with those obtained using a similar framework by Peri (2007). His analysis of the impact of migration on the California labor market stressed the absence of any significant employment effects of migrants on natives.
} 
over time as being supply driven. The response of relative wages identifies the inverse elasticity of substitution between new and old immigrants. The corresponding estimates are reported in Table 5. Different specifications check the robustness of results to different definitions of the sample, of immigrants, and of the education groups. Specification (1) adopts the basic specification described above, specification (2) does not include the imputed ethnic Germans among immigrants. Specification (3) includes men and women in the sample, specification (4) includes only people who worked full time during the year (meaning for at least 40 weeks) and specification (5) groups workers according to their occupation-industry imputed schooling. Finally specifications (6) and (7) consider two sub-samples and (8) and (9) adopt 2SLS as the estimation method using Eastern European immigrants as an instrument for total immigrants. The estimates are quite precise and consistent across specifications. The point estimates of the inverse elasticity are around 0.01 with a standard error also close to 0.01 . In most cases we can reject a value for the inverse elasticity larger than 0.03. Hence no evidence is found in any specification of imperfect substitutability between new and old immigrants. Thus, new and old immigrants are perfectly substitutable, $\lambda=\infty$ and

all immigrants belonging to each education-experience group $\left(M_{k j t}=M_{k j t}^{O L D}+M_{k j t}^{N E W}\right)$ can be considered as forming a homogeneous group of workers, which is what we assume in the remainder of the analysis.

\subsubsection{Natives and Immigrants}

Following the same strategy outlined in the previous section, we estimate the degree of substitutability between native and immigrant workers within education-experience cells. Specifically, we regress the logarithm of the relative wages of natives and immigrants on their relative employment levels with education, experience and year fixed effects to control for relative demand and productivity levels. Table 6 reports the values of $1 / \sigma$ from estimating the equation below:

$$
\ln \left(\frac{w_{M k j t}}{w_{H k j t}}\right)=D_{k}+D_{j}+D_{t}-\frac{1}{\sigma} \ln \left(\frac{M_{k j t}}{H_{k j t}}\right)+u_{k j t}
$$

Following the same type of specifications as in Table 5 we obtain a range of estimates of $1 / \sigma$. All columns now show significant values between 0.03 and 0.06 with standard errors around 0.01 and never larger than 0.02. While the values are not too large, they systematically indicate a degree of imperfect substitutability between natives and immigrants. These estimates are perfectly in line with what Ottaviano and Peri (2008) and Card (2009) estimate for the US (a value around 0.05), and are somewhat smaller than the values estimated for the UK by Manacorda et al. (2006), which range between 0.1 and 0.2. While small, these elasticity values, coupled with the large increase in immigrants relative to natives in most groups, delivers significant effects on the relative native- 
immigrant wage ratio. In particular, consider that the percentage of immigrants in Germany went from 9 to $14 \%$ between 1987 and 2001, implying an increase in the $\frac{M_{t}}{H_{t}}$ ratio for the aggregate economy of $64 \%$. This would imply, using the median estimate of 0.045 as the inverse elasticity, an increase in the wage of natives relative to immigrants of $0.045^{*} 0.64=2.8 \%$. Hence, combining the two pieces of evidence revealed by the regressions in Tables 4 and 6 we uncover a small but significant degree of imperfect substitutability between native workers and immigrant workers on the German labor market.

\subsubsection{Across Experience and Education Groups}

Following the implications of the model in section 3 we can use the expressions (10) and (11) to estimate $1 / \eta$ and $1 / \delta$, the inverse elasticity of substitution between experience and education groups. In particular, following Ottaviano and Peri (2008) we implement regressions (16) and (17) below:

$$
\begin{gathered}
\ln \left(\bar{W}_{k j t}\right)=D_{t}+D_{j}+\text { Time } \text { Trend }_{k}-\frac{1}{\eta} \ln \left(\widehat{L}_{k j t}\right)+u_{k j t} \\
\ln \left(\bar{W}_{k t}\right)=D_{t}+\text { Time } \text { Trend }_{k}-\frac{1}{\delta} \ln \left(\widehat{L}_{k t}\right)+u_{k t}
\end{gathered}
$$

The dependent variable is the log average wage in the education-experience group $\left(\bar{W}_{k j t}\right)$ or in the education $\left(\bar{W}_{k t}\right)$ group. In (16) we control for an education-specific time trend (Time Trend $\left.d_{k}\right)$ and for year $\left(D_{t}\right)$ and experience $\left(D_{j}\right)$ fixed effects, while in (17) we use time dummies and education-specific time trends $\left(\right.$ Time $_{\text {Trend }}$ ) to control for the change in cell-specific productivity. In both regressions we allow for a zero-mean disturbance. Instrumenting for the change in the cell labor-composites, $\widehat{L}_{k j t}$ and $\widehat{L}_{k t}$, with the inflow of immigrants (assumed to be supply-driven once we control for the fixed effects), we can obtain consistent estimates of the coefficients $1 / \eta$ and $1 / \delta$.

Table 7 reports the estimates of $1 / \eta$, which are between 0.31 and 0.33 . In column (1), the

supply index $\widehat{L}_{k j t}$ is constructed using a CES aggregator of native and immigrant employment with $1 / \sigma=0.046$. In column (2) the supply index is the simple sum of native and immigrant employment. Similarly, Table 8 presents the estimates of $1 / \delta$ which range between 0.34 when the supply index is constructed as a CES aggregate and 0.37 when the supply index is constructed as the sum of employment across education cells. These estimates imply an elasticity of substitution between education groups of around 2.9 and across experience groups of 3.3. The first is a bit larger than the corresponding estimates for the US (usually ranging between 1.5 and 2.5) and the second is slightly smaller than its US counterpart, usually estimated around 5 (see, e.g., Card and Lemieux (2001)). On the other hand, using a comparable sample Brucker and Jahn (2008) report 
estimated values for the parameter $1 / \delta$ close to 0.3 . While this is similar to ours, they estimate a lower value of $1 / \eta$ around 0.06 . The elasticity across age groups, however, does not play much of a role in our simulations in which we aim at characterizing the wage effect across education groups and between natives and immigrants. Hence, we use our estimated elasticity $1 / \eta$ in simulating the wage effects of immigration and reassure the reader that using the Brucker and Jahn (2008) elasticity estimates of $1 / \eta$ would give essentially identical results.

\subsection{Wage Effects}

Based on the theoretical framework of section 3 and, in particular, on the implied expressions (18) and (20) reported in the appendix, we are now able to evaluate the total impact of immigration on the wages of native and old migrant workers. In so doing, we rely on the employment effects estimated in section 5.2 and the elasticities of substitution $\sigma, \lambda, \eta$ and $\delta$ estimated in section 5.3. Section 5.4.1 analyzes the impact of the inflow of new immigrants between 1992 and 2001 on average wages and the total wage income of long-term (pre-1992) immigrants ${ }^{15}$. Then section 5.4.2 focuses on the impact of the same flow of immigrants on wages of native workers. We choose 1992 as a watershed because German migrants from East to West are reported in the dataset starting with that year.

\subsubsection{Wage Effects on Long-Term Immigrants, 1992-2001}

The effects of new immigration on the wages of long-term immigrants are given by expression (20). This allows us to compute the overall impact of post-1992 immigration on the wages of pre-1992 immigrant workers taking into account both the degree of substitutability between different groups of workers $(\delta, \eta, \sigma$ and $\lambda)$ and the response of employment to immigration flows $(\gamma)$. Following Ottaviano and Peri (2008) we also assume that the adjustment of capital to the inflow of immigrants is fast enough that the simulations obtained for full capital adjustment (to keep return to capital constant) are a good approximation for the actual effect experienced year-by-year in the economy.

Table 9 reports the simulated wage effects of immigration obtained using the average point estimates for the elasticity parameters, namely $\delta=2.9, \eta=3.3, \sigma=21.5, \lambda=58.1$ and $\gamma=0.69$. The terms on the right hand side of formula (20) in Appendix A can be sorted into three groups: each square bracket on the right hand side of (20) contains three groups of terms. The first terms (containing the expressions $\frac{\Delta M_{k j t}^{N E W}}{M_{k j t}^{N E W}}$ ) capture the direct effect of the change in the supply of new immigrants on wages. The second terms, containing the expressions $\left(\frac{\Delta M_{k j t}^{O L D}}{M_{k j t}^{O L D}}\right)_{\text {response }}$, capture the wage effect of the employment change of old immigrants in response to the inflow

\footnotetext{
${ }^{15}$ We define as post-1992 (pre-1992) immigrants who appear in our dataset 1992 or later (strictly before 1992).
} 
of new immigrants (the 'indirect effect') and is different from 0 . The third terms, containing the expressions $\left(\frac{\Delta H_{k j t}}{H_{k j t}}\right)_{\text {response }}$ capture the wage effect of a change in employment of natives in response to immigrants. This second group of indirect effects, however, is essentially zero in light of the results of Table 4 which reveal no employment response of natives to a change in immigrant employment. In Table 9 the direct and indirect effects of new immigrants are denoted by A and B, respectively. The table shows the direct, indirect and total wage effects of new immigration from Eastern Germany (columns 1-3), from the rest of the world including Ethnic Germans (columns 4-6) and the total effects, obtained by adding A and B (columns 7-9). Notice, intuitively, that the indirect effects, driven by the reduced employment of old immigrants, attenuate the negative wage impact of new immigrants on previous immigrants. This is because the reduction in old immigrants' employment is a partial offset for the increased supply of new immigrants.

Column (9) of Table 9 shows that the overall effects of ten years worth of new immigration on the wages of old immigrants are negative, implying an average loss for the pre-1992 immigrant workers of $0.5 \%$ of their real wage. This is not a particularly large number for two reasons: first, the inflow of new immigrants between 1992 and 2001 increased the share of foreign-born in employment by only 2.2 percentage points, which is a 20 percent increase in the initial level; second, the elasticity of substitution between natives and immigrants, while not infinite, is fairly large so that the effect of new immigrants on wages spreads in part to natives too. Old immigrant workers with a high level of education suffer the largest wage losses $(-1.11 \%)$, which is explained by the fact that post-1992 immigration to Western Germany is relatively high-skilled, mainly due to Eastern Germans (see in column 1 the direct effect of Eastern German immigration on wages of the highly educated). The comparison between columns 7, 8 and 9 reveals that the reduction in the employment levels of old immigrants, in response to immigration, attenuates the negative impact of immigration on the wages of those who keep their job by $0.78 \%$ on average, and by $1.5 \%$ for the highly educated.

Decomposing the overall wage effect with respect to the origin of immigrants, column 3 shows that immigration from Eastern Germany accounts for almost half of the negative wage effect for highly educated workers while it accounts for none of the negative effect on less educated workers. This is due to the fact that Eastern German immigrants are on average more educated than immigrants from the rest of the world. Thus, including Eastern Germans in the analysis contributes to a more balanced picture of the effect of immigrants to Western Germany, rather than focussing only on foreign immigrants (as is done in Felbermayr et al. (2008)).

All in all, Table 9 shows that the wage response of old immigrants to new immigrants is not too large. This leads us to inquire more carefully into the employment effect and to quantify it in 
terms of aggregate wage income lost. One way of doing this is to consider the effect of immigration on the wage bill of old immigrants. Table 10 reports the simulated effect of immigration 1992-2001 on the total wage bill of old immigrants. Such effect combines the decrease in employment and the decrease in the average wages of each worker who keeps her job. Combining employment and wage losses Table 10 reveals that immigration from Eastern Germany reduced the total wage bill of old immigrants by $5.7 \%$ and immigration from the rest of the world by $11.9 \%$. Again, immigration from Eastern Germany mostly penalized the highly educated, while immigration from the rest of the world had a more balanced effect. Overall, the wage bill of old immigrants was reduced by a substantial $17.6 \%$, and this loss was mainly driven by lost employment. These simulations already suggest that the imperfect labor market adjustment of wages, and the implied loss in employment for long-term immigrants were the most costly consequence of immigration. In particular, such an employment response, combined with generous unemployment benefits (as we will illustrate below) constituted a large burden on the German welfare system. The question is whether the aggregate cost of employment losses (lost production) and unemployment benefits is larger than the cost in terms of wage losses that old immigrants would have experienced in a flexible labor market in which wages would have adjusted to absorb the full inflow of immigrants without a reduction in the employment of old immigrants. These calculations will be performed in section 6

Summarizing the findings of this section, we can say that new immigrants penalized old immigrants primarily in terms of employment, and only a small amount by decreasing their wages. In terms of wages, old immigrants with high education and old immigrants with no vocational education were the groups hurt the most.

\subsubsection{Wage Effects on Natives, 1987-2001}

Turning to the effects of immigration on native wages, we use expression (18). Following our findings in sections 5.2.2 and 5.3.2, we impose the absence of employment effects for natives $(\rho=1)$ as well as imperfect substitutability between native and immigrant workers.

Table 11 reports the simulated wage effect for natives with three different educational attainments over the period 1992-2001. In the first column we report the results when we consider imperfect substitutability between natives and immigrants and in column 2 we report, for reference, those obtained assuming perfect substitutability between natives and immigrants. As in most specifications of Table 5 we find a significant inverse elasticity $1 / \sigma$, though we prefer the results of column 1 which uses the average estimated value for $\sigma$ equal to 21.5. With imperfect substitutability, column (1) shows no average impact of immigration on native wages over the period 1992-2001. Across educational levels, relatively low educated workers experience a moderate improvement in 
their wage levels $(+1.68 \%)$, while highly educated ones suffer a small loss $(-1 \%)$. This is again due to the fact that, during the period of observation, immigration to Germany (mostly from Eastern Germany) was relatively skilled. These small wage effects are consistent with the absence of negative employment effects found in section 5.2.2. Moreover, even when, in column (2), we impose perfect substitutability $(\sigma=\infty)$ between natives and immigrants, the overall effect on wages is negative but still very close to zero, with the same distributional pattern across educational groups as in the case of $\sigma=21.5$.

Hence, new immigrants did not penalize native workers much either in terms of employment or in terms of wages. Indeed, native workers with low education experienced a rise in their wages.

\section{Wage Rigidity and the Costs of Immigration}

The main finding of the previous section is that new immigrants did not affect native workers much in terms of either employment or wages, while they did have a negative impact on old immigrants, mostly in terms of employment and only a little in terms of wages.

In this section we propose a simple calculation whose aim is to produce an aggregate monetary amount which quantifies the cost of the rigidities and unemployment benefits in the presence of new immigration. First, we calculate how much new immigration costs in terms of foregone output and unemployment insurance, assuming that all old immigrants displaced by new immigrants are indeed covered by insurance. Second, we calculate the changes that natives' and immigrants' wages would undergo if wages adjusted to completely eliminate the employment effects on old immigrants.

Our calculations focus on the year 2001. The results of the first calculation are shown at the bottom of Table 12 where all values are expressed in constant Euros at year 2000 prices. Column (1) shows that, based on an estimate of $\gamma=0.69$, approximately 25,600 old immigrants were displaced by the inflow of new immigrants in 2001. This number of displaced workers can be multiplied by the average yearly wage of old immigrants (equal to 25,996 as shown in column (3)) to obtain the 665 million Euros of foregone wage income reported in column (5). On top of this cost, the total yearly cost sustained to fund the unemployment insurance is shown in column (4), which multiplies the number of displaced old immigrant workers by unemployment insurance payments. Following Adema et al. (2003), these payments are set at 14,449 Euros per displaced worker, leading to the total value of 370 million Euros. This is just a lower bound estimate of the overall cost borne by taxpayers because the full cost should also include unemployment assistance (for the long-term unemployed), housing benefits, active labor market policies, etc. Thus, in the presence of employment effects associated with wage rigidity, in 2001 the overall yearly costs of new immigration in foregone wages and unemployment benefits was around 1 billion Euros. 
Table 13 reports what would have happened to the wages of natives and old immigrants if the latter's wages had been allowed to fall with no adverse employment effect. Based on (18), (20) and parameter estimates, column (3) shows that the employment effects on old immigrants would have disappeared if their average wage had fallen by $0.15 \%$ relative to its actual level, with a corresponding rise of $0.016 \%$ in native wages. ${ }^{16}$ These percentage variations are first multiplied by the average yearly wages in column (2), then by the employment levels in column (1) to obtain the overall changes in the wage bills paid to native and old immigrant workers. ${ }^{17}$ These are reported in column (5) where old immigrants suffer in aggregate a wage decrease of 57 million Euros whereas natives enjoy a wage increase of slightly less than 43 million Euros. Hence, the immigration of 2001, with no employment response and full wage adjustment would have implied a decrease in the total wage bill of natives and old immigrants equal to 14 million Euros. Table 13 shows also the wage effect for each education group in the presence of no employment effects. The group receiving the biggest loss is that of highly educated old immigrants who would experience a decrease of 158 Euros per year. This is to be expected, since new immigrants have been relatively highly educated. Column 5 shows the total wage losses by education and nativity group under the scenario of no employment effect (and full wage adjustment). Column 7 shows, by comparison, the overall costs sustained to finance unemployment benefits for displaced immigrants (in the case of wage rigidities) if those were funded by a tax proportional to the wage level of each worker, thus penalizing the relatively better educated. The cost of unemployment on the employed old immigrants and on natives is much (twenty times) larger under the scenario of wage rigidity and unemployment insurance than in the scenario with full wage flexibility and no effect on employment.

To sum up, immigration seems to be much more costly when labor market adjustment happens mostly via the employment margin rather than through the wage margin. The institutional characteristics of the German labor market, such as the very generous unemployment benefits scheme (virtually open-ended, long-term unemployment assistance, "Arbeitslosenhilfe", was abolished only in 2005), deteriorated the possibility of an efficient absorption of the migration supply shock which occurred in that period. This result is in line with Angrist and Kugler (2003), who argue that the reaction of a country's labor market to immigration depends on its institutional features and, in particular, that more 'flexible' labor markets are more effective in absorbing the supply shocks arising from migrant inflows. In recent times, a series of reforms have increased the flexibility of the German labor market. In 2002, the Job-Aqtiv Act increased the sanctions on the unemployed for refusing a job offer. Starting in 2003, the so-called Hartz reforms reduced the level, as well as

\footnotetext{
${ }^{16}$ The wages of natives rise thanks to the imperfect substitutability between natives and immigrants.

${ }^{17}$ Average yearly wages are computed from our sample by multiplying the average daily wages by the average number of days worked in a year.
} 
the duration, of unemployment benefits, rationalized the overall social assistance scheme in order to increase the incentives to work, further restricted the acceptable reasons for rejecting a job offer without losing benefits, and liberalized employment services (Ebbinghas and Eichhorst, 2009; Eichhorst and Kaiser, 2006). In general, the aim of these reforms was to accelerate labor market flows (Fahr and Sunde, 2006) and to increase the incentives to work. Coupled with the diffusion of opening clauses from collective contracts (OECD, 2006), these reforms have increased the flexibility of the German labor market and thus the capacity to deal efficiently with labor supply shocks due to migration. Interestingly, in our context, among the beneficiaries of such flexibility are the long-term immigrants: with more flexibility they can retain their jobs (not be displaced), although at a lower wage. The benefit to other citizens is in the form of lower taxes, under the assumption that unemployment insurance is funded by a general tax.

\section{Conclusion}

This paper contributes to the recently revived literature analyzing the impact of immigration within a labor market equilibrium framework fully accounting for the interactions between production factors (Aydemir and Borjas, 2007; Borjas, 2003; Manacorda et al., 2006; Ottaviano and Peri, 2008; Peri, 2007). With respect to this literature, we have made some methodological progress. First, the elasticity parameters necessary to disentangle the wage effects of immigration have been estimated with higher precision, exploiting a large yearly panel of German workers and using the large inflow of Eastern Germans after the fall of the Berlin Wall as an exogenous shock. Second, we have allowed for imperfect substitution not only between immigrants and natives but also between old and new immigrants. Third, in order to better estimate the impact of new immigrants on old ones, we have extended the labor market equilibrium approach to allow for employment responses driven by wage rigidities. Taking these responses into account, we have been able to distinguish between the 'direct effect' of immigration, which refers to the change in wages taking place for given employment levels of natives and old immigrants, and the 'indirect effect', which refers to the change in wages due to changes in those employment levels.

Looking at the employment effects of immigration, we have found that new immigration has had a negative impact on the employment of old immigrants and no impact on the employment of natives, suggesting closer competition between new and old immigrants than between immigrants and natives as well as different insider-outsider status of natives and immigrants. The estimated wage effects of new immigrants are on average very small for natives and small and negative for old immigrants.

All in all, the most statistically and economically significant impact of new immigration is 
the negative employment effect on old immigrants driven by wage rigidities. In a counterfactual experiment, we have quantified the implications of such rigidities in terms of aggregate costs of immigration. The calculations, based on the estimated elasticities, indicate that removing the negative employment effects of new immigration on old immigrants would cause small wage losses to old immigrants but would save much more, in the aggregate, on unemployment benefits. If workers fund the unemployment benefits with taxes, the savings in taxes more than compensate their wage losses. 


\section{References}

Acemoglu, D. and J. D. Angrist (2001). Consequences of Employment Protection? The Case of the Americans with Disabilities Act. Journal of Political Economy (109), 915-957.

Adema, W., D. Gray, and S. Kahl (2003). Social Assistance in Germany. OECD Labour Market and Social Policy Occasional Papers (58).

Angrist, J. and A. Kugler (2003). Protective or Counter-Productive? Labour Market Institutions and the Effect of Immigration on EU Natives. Economic Journal (113), 302-331.

Aydemir, A. and G. Borjas (2007). Cross-Country Variation in the Impact of Imternational Migration: Canada, Mexico, and the united States. Journal of the European Economic Association (5), $663-708$.

Bauer, T., B. Dietz, K. F. Zimmermann, and E. Zwintz (2005). German Migration: Development, Assimilation, and Labour Market Effects. In K. F. Zimmermann (Ed.), European Migration: What Do We Know?, pp. 197-261. Oxford University Press.

Bauer, T. and K. F. Zimmermann (1997). Unemployment and Wages of Ethnic Germans. Quarterly Review of Economics and Finance (37), 361-377.

Bender, S., H. Anette, and C. Klose (2000). IAB Employment Subsample 1975-1995. Opportunities for Analysis Provided by the Anonymised Subsample. IZA Discussion Paper (117).

Bonin, H. (2005). Wage and employment effects of immigration in germany: Evidence from a skill group approach. IZA Discussion Paper (1875).

Borjas, G. (2003). The Labor Demand Curve is Downward Sloping: Reexamining the Impact of Immigration on the Labor Market. Quarterly Journal of Economics (118), 1335-1374.

Borjas, G. and L. F. Katz (2007). The Evolution of the Mexican-Born Workforce in the United States. In G. Borjas (Ed.), Mexican Immigration to the United States. National Bureau of Economic Research.

Bound, J., D. A. Jaeger, and R. M. Baker (1995). Problems with Instrumental Variables Estimation When the Correlation Between the Instruments and the Endogeneous Ex- planatory Variable is Weak. Journal of the American Statistical Association (90), 443-450.

Brucker, H. and E. J. Jahn (2008). Migration and the Wage Curve: a Structural Approach to Measure the Wage and Employment Effects of Migration. IZA Discussion Paper (3423). 
Bundesverwaltungsamt (2003). Jahresstatistik Aussiedler.

Card, D. (2001). Immigrant Inflows, Native Outflows, and the Local Market Impacts of Higher Education. Journal of Labor Economics (19), 22-64.

Card, D. (2007). How Immigration Affects U.S. Cities. CREAM Discussion Papers Series (11).

Card, D. (2009). Immigration and Inequality. NBER Working Paper (14683).

Card, D. and T. Lemieux (2001). Can Falling Supply Explain the Rising Returns to College for Younger Men? A Cohort Based Analysis. Quarterly Journal of Economics (116), 705-746.

D'Amuri, F., G. Ottaviano, and G. Peri (2008). The Labor Market Impact of Immigration in Western Germany in the 1990's. NBER Working Paper (13851).

De New, J. P. and K. F. Zimmermann (1994). Native wage impacts of foreign labor: a random effects panel analysis. Journal of Population Economics (7), 177-192.

Dustmann, C., T. Frattini, and I. Preston (2007). Immigration and Wages: New Evidence for Britain. University College of London, mimeo.

Ebbinghas, B. and W. Eichhorst (2009). Employment Regulation and Labor Market Policy in Germany, 1991 - 2005. In P. de Beer and T. Schils (Eds.), Social Policy and the Labour Market: Achieving an Optimal Policy Mix, Cheltenham. Edward Elgar.

Eichhorst, W. and L. C. Kaiser (2006). The German Labor Market: Still Adjusting Badly? IZA Discussion Paper (2215).

Fahr, R. and U. Sunde (2006). Did the Hartz Reforms Speed-Up Job Creation? A Macro-Evaluation Using Empirical Matching Functions. IZA Discussion Paper (2470).

Felbermayr, G. J., W. Geis, and W. Kohler (2008). Restrictive Immigration Policy in Germany: Pains and Gains Foregone? CESifo Working Paper (2316).

Friedberg, R. M. (2001). The Impact of Mass Migration on the Israeli Labor Market. Quarterly Journal of Economics (116), 1373-1408.

Glitz, A. (2006). The Labour Market Impact of Immigration: Quasi-Experimental Evidence. CREAM Discussion Paper (12/06).

Haisken-DeNew, J. P. and J. R. Frick (2005). Desktop Companion to the German Socio-Economic Panel (SOEP). 
ILO (2007). Key Indicators of the Labour Market (5th edition).

Manacorda, M., A. Manning, and J. Wadsworth (2006). The Impact of Immigration on the Structure of Male Wages: Theory and Evidence from Britain. CEP Discussion Paper, London School of Economics (754).

OECD (2006). Labour market reform should go on. Economic Surveys: Germany.

Ortega, F. and G. Peri (2009). The Causes and Effects of International Migrations: Evidence from OECD Countries 1980-2005. UC Davis, Manuscript (February).

Ottaviano, G. and G. Peri (2008). Immigration and the National Wages: Clarifying the Theory and the Empirics. NBER Working Paper (14188).

Peri, G. (2007). Immigrants' Complementarities and Native Wages: Evidence from California. NBER Working Paper (12956).

Peri, G. and C. Sparber (2009). Task Specialization, Immigration, and Wages. American Economic Journal: Empirical Economics, forthcoming.

Pischke, J. S. and J. Velling (1997). Employment effects of immigration to Germany: An analysis based on local labor markets. Review of Economics and Statistics (79), 594-604.

Romer, D. (2001). Advanced Macroeconomics. McGraw-Hill.

Saint-Paul, G. (1996). Dual Labor Markets: A Macroeconomic Perspective. Cambridge: MIT press.

Schmidt, C. M., A. Stiltz, and K. F. Zimmermann (1994). Mass Migration, Unions, and Government Intervention. Journal of Public Economics (55), 185-201.

Statistisches-Bundesamt-Deutschland (2006a). Bevolkerung und erwerbsttigkeit.

Statistisches-Bundesamt-Deutschland (2006b). Information zur OstWest Wanderung.

Stock, J. H. and M. Yogo (2002). Testing for Weak Instruments in Linear IV Regression. NBER Technical Working Papers (0284).

Zimmermann, K. F. (1999). Ethnic German Migration since 1989 - Results and Perspectives. IZA Discussion Paper (50).

Zimmermann, K. F., H. Bonin, R. Fahr, and H. Hinte (2007). Immigration Policy and the Labor Market. Berlin: Springer - Verlag. 


\section{A Derivation of Wage Effects}

As discussed in section 3.3, the overall impact of new immigration on wages paid to native workers is obtained by computing the total change of equation (8) with respect to the changes in all the labor aggregates $\left(L_{t}, L_{k t}, L_{k j t}\right)$ induced by new immigrants in the various education and experience groups. Specifically, we can write:

$$
\begin{aligned}
\left(\frac{\Delta w_{H k j t}}{w_{H k j t}}\right)^{\text {Total }}= & \frac{1}{\delta} \sum_{m} \sum_{i}\left[s_{M m i t} \frac{\Delta M_{\text {mit }}}{M_{\text {mit }}}+s_{\text {Hmit }}\left(\frac{\Delta H_{\text {mit }}}{H_{\text {mit }}}\right)_{\text {response }}\right] \\
& +\left(\frac{1}{\eta}-\frac{1}{\delta}\right) \frac{1}{s_{k t}} \sum_{i}\left[s_{\text {Mkit }} \frac{\Delta M_{k i t}}{M_{k i t}}+s_{H k i t}\left(\frac{\Delta H_{k i t}}{H_{k i t}}\right)_{\text {response }}\right] \\
& +\left(\frac{1}{\sigma}-\frac{1}{\eta}\right) \frac{1}{s_{k j t}}\left[s_{M k j t} \frac{\Delta M_{k j t}}{M_{k j t}}+s_{H k j t}\left(\frac{\Delta H_{k j t}}{H_{k j t}}\right)_{\text {response }}\right]-\frac{1}{\sigma}\left(\frac{\Delta H_{k j t}}{H_{k j t}}\right)_{\text {response }}^{\text {(18) }}
\end{aligned}
$$

where the variable $s_{M k j t}=w_{M k j t} M_{k j t} / \sum_{m} \sum_{i}\left(w_{M m i t} M_{m i t}+w_{H m i t} H_{m i t}\right)$ is the share of total wage income paid to migrant workers of education $k$ and experience $j$ in year $t$ and $s_{H k j t}$ is the share of wage income paid to native workers in the same education-experience group. Similarly, $s_{k j t}=\left(w_{M k j t} M_{k j t}+w_{H k j t} H_{k j t}\right) / \sum_{m} \sum_{i}\left(w_{M m i t} M_{m} i t+w_{H m i t} H_{m i t}\right)$ is the share of wage income paid to all workers of education $k$ and experience $j$ in year $t, s_{k t}$ is the wage share paid to all workers with education $k$ in year $t$, and so on. The first double summation captures the crosseffects of immigration in groups of any education-experience level, the second summation captures the effects of immigration in groups with the same education at all experience levels, and the third and fourth summations capture the effects of immigrants within the same education-experience group.

The term $\Delta M_{k j t} / M_{k j t}=\left(M_{k j t+1}-M_{k j t}\right) / M_{k j t}$ represents the change in the supply of immigrant workers with education $k$ and experience $j$ between $t$ and $t+1$. Analogously, the term $\left(\Delta H_{k j t} / H_{k j t}\right)_{\text {response }}$ represents the change in labor supply of native workers in the same group caused by immigration. These terms account for the employment effects of immigration that arise in the presence of a positive relationship between native and old immigrant workers' wages and employment levels as in (6) and (7):

$$
\begin{aligned}
\left(\frac{\Delta H_{k j t}}{H_{k j t}}\right)_{\text {response }} & =\xi^{H} \frac{\Delta w_{H k j t}}{w_{H k j t}}, \\
\left(\frac{\Delta M_{k j t}^{O L D}}{M_{k j t}^{O L D}}\right)_{\text {response }} & =\xi^{M} \frac{\Delta w_{H k j t}^{O L D}}{w_{H k j t}^{O L D}}, \\
\frac{\Delta M_{k j t}}{M_{k j t}} & =\frac{\Delta M_{k j t}^{O L D}+\Delta M_{k j t}^{N E W}}{M_{k j t}^{O L D}+M_{k j t}^{N E W}}
\end{aligned}
$$


Taken together with (18), expressions (19) imply that employment effects will have consequences for the impact of immigration on wages. A complete analytical solution of the effects of immigration on wages would require substituting expressions (19) into (18) and then solving for $\Delta w_{H k j t} / w_{H k j t}$ as a function of the change in new immigrants $\Delta M_{k j t}^{N E W} / M_{k j t}^{N E W}$ only. That would lead to a reduced form dependence of wages in each group on immigration, incorporating demand and supply parameters. In our empirical implementation, however, since we can observe $\Delta H_{k j t} / H_{k j t}$ and $\Delta M_{k j t}^{O L D} / M_{k j t}^{O L D}$ we estimate empirically their supply response to $\Delta M_{k j t}^{N E W} / M_{k j t}^{N E W}$ (see equation 13) and then include this estimation into (18).

Similarly, we can express the long run effect of new immigrants on old immigrants' wages as:

$$
\begin{aligned}
\left(\frac{\Delta w_{M k j t}^{O L D}}{w_{M k j t}^{O L D}}\right)^{\text {Total }} & =\frac{1}{\delta} \sum_{m} \sum_{i}\left[s_{\text {mit }}^{N E W} \frac{\Delta M_{m i t}^{N E W}}{M_{m i t}^{N E W}}+s_{m i t}^{O L D}\left(\frac{\Delta M_{m i t}^{O L D}}{M_{m i t}^{O L D}}\right)_{\text {response }}+s_{H m i t}\left(\frac{\Delta H_{\text {mit }}}{H_{\text {mit }}}\right)_{\text {response }}\right] \\
& +\left(\frac{1}{\eta}-\frac{1}{\delta}\right) \frac{1}{s_{k t}} \sum_{i}\left[s_{k i t}^{N E W} \frac{\Delta M_{k i t}^{N E W}}{M_{k i t}^{N E W}}+s_{k i t}^{O L D}\left(\frac{\Delta M_{k i t}^{O L D}}{M_{k i t}^{O L D}}\right)_{\text {response }}+s_{H k i t}\left(\frac{\Delta H_{k i t}}{H_{k i t}}\right)_{\text {response }}\right] \\
& +\left(\frac{1}{\sigma}-\frac{1}{\eta}\right) \frac{1}{s_{k j t}}\left[s_{k j t}^{N E W} \frac{\Delta M_{k j t}^{N E W}}{M_{k j t}^{N E W}}+s_{k i t}^{O L D}\left(\frac{\Delta M_{k j t}^{O L D}}{M_{k j t}^{O L D}}\right)_{\text {response }}+s_{H k j t}\left(\frac{\Delta H_{k j t}}{H_{k j t}}\right)_{\text {response }}\right] \\
& +\left(\frac{1}{\lambda}-\frac{1}{\sigma}\right) \frac{1}{s_{M k j t}}\left[s_{k j t}^{N E W} \frac{\Delta M_{k j t}^{N E W}}{M_{k j t}^{N E W}}+s_{k i t}^{O L D}\left(\frac{\Delta M_{k j t}^{O L D}}{M_{k j t}^{O L D}}\right)_{\text {response }}\right]-\frac{1}{\lambda}\left(\frac{\Delta M_{k j t}^{O L D}}{M_{k j t}^{O L D}}\right)_{\text {response }}
\end{aligned}
$$

Hence, once the parameters $\delta, \eta, \sigma$ and $\lambda$ are estimated and once we know the employment responses of old immigrants and native workers to new immigrants, we are able to calculate the wage effect of immigration for each group.

\section{B Imputation of Ethnic German Immigrants}

A worker is considered as Western German if her nationality is German and if she has always been working in Western Germany. All the others are considered as immigrants. Eastern Germans, in particular are considered as immigrants. They are identified as individuals with German nationality who started working in the East and then moved to the West within the considered period. Foreign migrants are individuals who have a non-German nationality or are ethnic Germans coming from abroad. Particular attention is devoted to identifying the ethnic German group of immigrants. These are immigrants mostly from Eastern European countries and, as discussed in section 2, tend to behave just like other immigrants from those countries. However, they are barely distinguishable from Western German nationals in the data set. With the end of the Cold War a large number of ethnic Germans (slightly less than 3 million over the period 1989-2001, according to Bundesverwaltungsamt (2003)) previously living in Eastern Europe moved to Western Germany, 
settling there permanently. ${ }^{18}$ After having successfully applied for a visa in the German embassy in their country of origin, those immigrants were allowed to enter Germany, enjoying unrestricted rights of German citizenship upon arrival.

Since in the IAB dataset only nationality identifiers are reported, we are not able to distinguish ethnic German workers from Western German workers in the individual records. However, omitting their inflows would distort our analysis, especially as they were correlated over time with immigrants from Eastern Germany and from other foreign countries. Indeed, ethnic Germans were mostly born abroad and were not able to speak German fluently on their arrival, hence they were in all respects more comparable to immigrants than to Western German nationals. As reported in section 2, the perception is that "Ethnic Germans are basically facing the same difficulties with social and economic integration as foreigners" (Zimmermann, 1999) and, therefore, they should be considered as foreign immigrants in our context.

We estimate the total inflow of ethnic Germans in each education-experience-year group and then identify the impact of such an inflow (together with those of Eastern Germans and foreigners) on the employment levels and wages of previous immigrants and native Germans. To construct the estimates, we merge different sources of information. First, we obtain $E_{x t}$, the total yearly inflow of ethnic Germans by year of arrival $t$ and country of origin $x$ from Bundesverwaltungsamt (2003) and Statistisches-Bundesamt-Deutschland (2006b), respectively. Then, from the IAB data we retrieve the exact information on the characteristics and labor market performance of foreign immigrants coming from the same set of countries in the same year of arrival as ethnic Germans. ${ }^{19}$ Finally, we assume that, for country of origin $x$ and year of arrival $t$, the educational and age composition of ethnic Germans is identical to that of foreign immigrants and that, within education-experience cells, ethnic Germans and foreign immigrants from the same country of origin have exactly the same labor market performance in terms of employment levels and wages. For example, we consider ethnic Germans who migrated to Western Germany from the Czech Republic in 1994 as exactly mirroring the observed and unobserved characteristics of the group of Czech citizens migrating to Western Germany in the same year.

Specifically, as a first step, for each of the major ethnic Germans' countries of origin $x$ and each year $t$, we construct $f_{x k j t}=M_{x k j t} / M_{x t}$ as the share of immigrant workers with education $k$ and experience $j$ in the total immigrant flow. Notice that the total inflow of immigrants from country $x$ and year $t, M_{x t}$ is obtained from Bundesverwaltungsamt (2003) and Statistisches-BundesamtDeutschland (2006b) while the number in each education-specific group $M_{x k j t}$ is taken from the

\footnotetext{
${ }^{18}$ See Bauer and Zimmermann (1997) for an analysis of the labor market integration of ethnic German workers.

${ }^{19}$ The countries are: Czech Republic, Slovakia, former Soviet Union, former Yugoslavia, Hungary, Poland, Romania.
} 
IAB. Hence the share $f_{x k j t}$ corrects for the employment/population ratio and allows us to impute employment in each group from the total population of immigrants. We then calculate the imputed number of immigrant ethnic German workers from country $x$ with education $k$ and experience $j$ in year $t$ as:

$$
E_{x t k j}=E_{x t} f_{x t k j}
$$

Since the inflows of ethnic Germans and foreign immigrants from a specific country $x$ can be highly volatile, our second step is to smooth the imputed values by taking averages over two consecutive years. We then attribute to each group $E_{x t k j}$ the average wage of foreign immigrants coming from the same country $x$ in the same year $t$ and with the same education and age. After those two steps, we obtain a complete education-experience distribution of employment and wages for the ethnic German immigrants by country of origin $x$ and year of arrival $t$. Summing across different years of arrival (starting with 1987) and countries of origin, we finally obtain the employment levels within education-experience cells for each year. Similarly, the cell-specific wages are reconstructed using a weighted average of average wages by country of origin and year of arrival. As a final step, we subtract the imputed employment levels by cell from the analogous cells of the native Western German population and we add them to the immigrant population. 


\section{Tables and Figures}

Table 1

Comparison between IAB and GSOEP, Year 1987, 1991 and 2001

\begin{tabular}{|c|c|c|c|c|c|c|c|c|c|c|c|c|c|}
\hline & & \multicolumn{4}{|c|}{1987} & \multicolumn{4}{|c|}{1991} & \multicolumn{4}{|c|}{2001} \\
\hline & & \multicolumn{2}{|c|}{ GSOEP } & \multicolumn{2}{|c|}{ IAB } & \multicolumn{2}{|c|}{ GSOEP } & \multicolumn{2}{|c|}{ IAB } & \multicolumn{2}{|c|}{ GSOEP } & \multicolumn{2}{|c|}{ IAB } \\
\hline & & Mean & S. D. & Mean & S. D. & Mean & S. D. & Mean & S. D. & Mean & S. D. & Mean & S. D. \\
\hline \multirow{7}{*}{ Natives } & Share Females & 0.40 & & 0.42 & & 0.40 & & 0.43 & & 0.46 & & 0.44 & \\
\hline & No Vocational Education & 0.21 & & 0.26 & & 0.25 & & 0.22 & & 0.16 & & 0.18 & \\
\hline & Vocational Education & 0.66 & & 0.68 & & 0.65 & & 0.71 & & 0.64 & & 0.71 & \\
\hline & Higher Education & 0.12 & & 0.06 & & 0.10 & & 0.07 & & 0.20 & & 0.11 & \\
\hline & Years of experience & 17.73 & 11.77 & 16.90 & 11.28 & 17.69 & 11.40 & 17.67 & 11.10 & 19.58 & 10.60 & 19.52 & 10.72 \\
\hline & $\begin{array}{l}\text { Less than } 20 \text { years of pot. } \\
\text { Exp }\end{array}$ & 0.59 & & 0.62 & & 0.60 & & 0.60 & & 0.53 & & 0.53 & \\
\hline & Daily wage & 64.74 & 39.39 & 68.87 & 33.25 & 65.31 & 42.16 & 75.09 & 33.56 & 73.78 & 46.97 & 79.15 & 39.37 \\
\hline \multirow{8}{*}{ Immigrants } & Share of total & 0.07 & & 0.09 & & 0.12 & & 0.10 & & 0.13 & & 0.14 & \\
\hline & Share Females & 0.30 & & 0.31 & & 0.33 & & 0.33 & & 0.40 & & 0.37 & \\
\hline & No Vocational Education & 0.61 & & 0.62 & & 0.66 & & 0.59 & & 0.29 & & 0.38 & \\
\hline & Vocational Education & 0.36 & & 0.34 & & 0.31 & & 0.37 & & 0.46 & & 0.54 & \\
\hline & Higher Education & 0.03 & & 0.04 & & 0.02 & & 0.04 & & 0.25 & & 0.08 & \\
\hline & Years of experience & 20.59 & 10.75 & 18.64 & 10.15 & 20.37 & 11.98 & 18.22 & 10.69 & 17.88 & 11.09 & 18.68 & 10.56 \\
\hline & $\begin{array}{l}\text { Less than } 20 \text { years of pot. } \\
\text { Exp }\end{array}$ & 0.46 & & 0.54 & & 0.47 & & 0.56 & & 0.61 & & 0.58 & \\
\hline & Daily wage & 56.78 & 21.25 & 68.54 & 26.75 & 54.32 & 22.25 & 70.83 & 29.10 & 65.77 & 44.97 & 71.85 & 32.87 \\
\hline
\end{tabular}

Note: The German Socio-Economic Panel GSOEP is a panel of individuals started in 1984 with refreshments (i.e. inclusion of new waves of people) in 1994/1995, 1998 and 2000 over the considered period. The IAB is an administrative dataset including all workers contributing to social security. Immigrants are defined as foreign-born plus those living in East Germany in 1989 in the GSOEP and as foreign-nationals plus those who report having started to work in East Germany in the IAB. 
Table 2

Share of Foreign Immigrants/Eastern German Immigrants in total workers by education and potential experience

\begin{tabular}{|c|c|c|c|cc|}
\hline \multirow{5}{*}{ Education } & Potential & 1987 & \multicolumn{3}{|c|}{2001} \\
\cline { 3 - 6 } & Experience & $\begin{array}{c}\text { Overall } \\
\text { share of } \\
\text { migrants }\end{array}$ & $\begin{array}{c}\text { Overall } \\
\text { share of } \\
\text { migrants }\end{array}$ & $\begin{array}{c}\text { Share } \\
\text { East- } \\
\text { West } \\
\text { Germans }\end{array}$ & $\begin{array}{c}\text { Share } \\
\text { Foreign } \\
\text { Immigrants }\end{array}$ \\
\hline \multirow{5}{*}{ No } & Up to 4 & $7.2 \%$ & $8.8 \%$ & $1.0 \%$ & $7.8 \%$ \\
Vocational & 5 to 9 & $20.6 \%$ & $22.9 \%$ & $2.9 \%$ & $20.0 \%$ \\
Education & 10 to 14 & $20.1 \%$ & $42.5 \%$ & $3.7 \%$ & $38.8 \%$ \\
& 15 to 19 & $24.7 \%$ & $39.3 \%$ & $3.4 \%$ & $35.9 \%$ \\
& 20 to 24 & $32.4 \%$ & $35.7 \%$ & $2.5 \%$ & $33.2 \%$ \\
& 25 to 29 & $38.1 \%$ & $27.9 \%$ & $3.0 \%$ & $24.9 \%$ \\
& 30 to 34 & $23.3 \%$ & $26.1 \%$ & $2.4 \%$ & $23.8 \%$ \\
& 35 to 40 & $16.4 \%$ & $33.7 \%$ & $1.5 \%$ & $32.2 \%$ \\
\hline \multirow{5}{*}{ Vocational } & Up to 4 & $4.9 \%$ & $15.4 \%$ & $5.0 \%$ & $10.4 \%$ \\
& 5 to 9 & $4.0 \%$ & $18.2 \%$ & $5.5 \%$ & $12.7 \%$ \\
& 10 to 14 & $4.2 \%$ & $14.1 \%$ & $4.9 \%$ & $9.2 \%$ \\
& 15 to 19 & $5.5 \%$ & $11.1 \%$ & $3.8 \%$ & $7.3 \%$ \\
& 20 to 24 & $7.7 \%$ & $9.6 \%$ & $3.8 \%$ & $5.8 \%$ \\
& 25 to 29 & $4.9 \%$ & $8.4 \%$ & $3.3 \%$ & $5.1 \%$ \\
& 30 to 34 & $3.4 \%$ & $9.1 \%$ & $2.7 \%$ & $6.5 \%$ \\
& 35 to 40 & $2.8 \%$ & $8.7 \%$ & $1.9 \%$ & $6.8 \%$ \\
\hline Higher & 15 to 19 & $7.5 \%$ & $7.7 \%$ & $2.8 \%$ & $4.9 \%$ \\
& Up to 4 & $4.8 \%$ & $13.7 \%$ & $3.8 \%$ & $10.0 \%$ \\
& 5 to 9 & $4.3 \%$ & $8.9 \%$ & $3.0 \%$ & $5.8 \%$ \\
& 10 to 14 & $5.7 \%$ & $7.9 \%$ & $2.9 \%$ & $5.0 \%$ \\
& 25 to 24 & $6.4 \%$ & $8.2 \%$ & $2.9 \%$ & $5.4 \%$ \\
& 25 to 29 & $4.3 \%$ & $9.4 \%$ & $2.8 \%$ & $6.5 \%$ \\
& 30 to 34 & $4.2 \%$ & $10.1 \%$ & $3.3 \%$ & $6.8 \%$ \\
& 35 to 40 & $0.0 \%$ & $10.0 \%$ & $2.9 \%$ & $7.1 \%$ \\
\hline
\end{tabular}

Note: The percentages are calculated from IAB data refined as described in the main text. Immigrants are defined as foreign-nationals and foreign-born ethnic Germans. East-West Germans are those workers who report having started to work in East Germany. 
Table 3

Estimates of $\gamma$ : the employment effects of new immigrants on previous immigrants

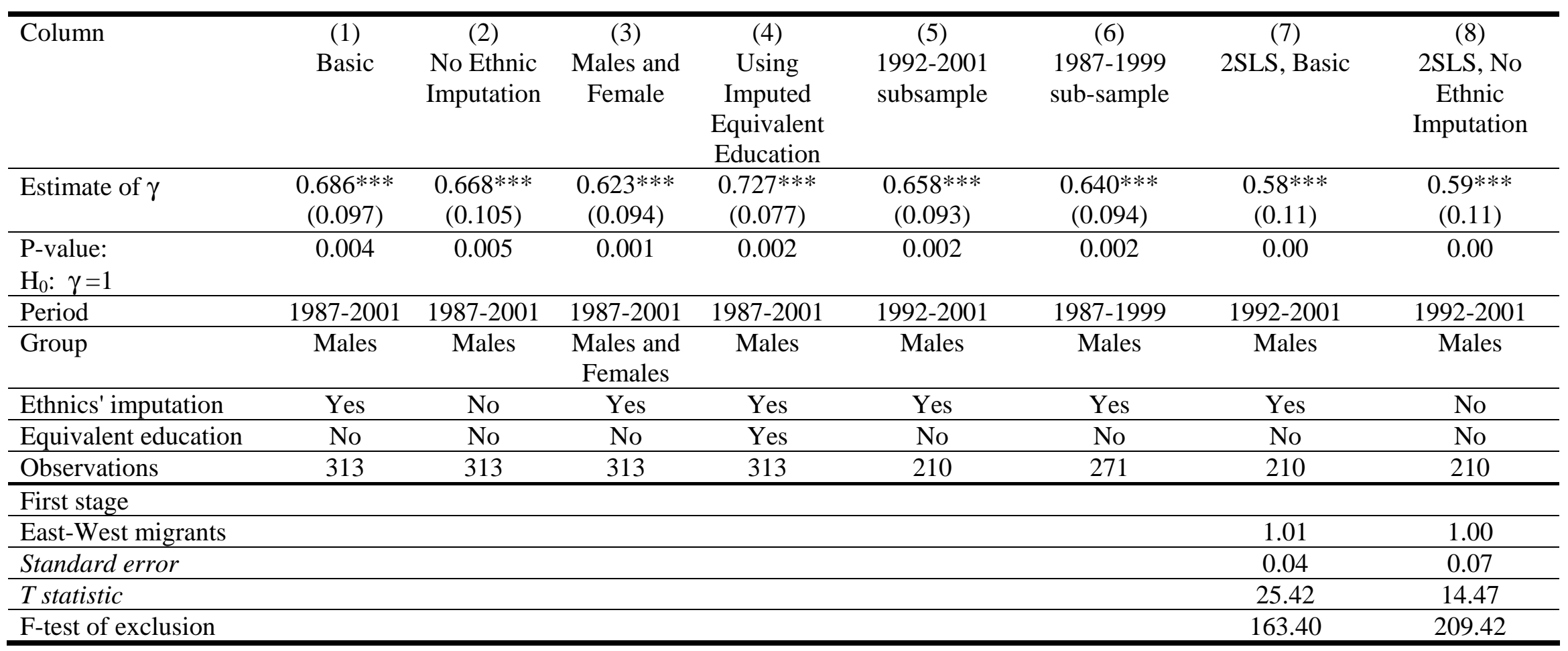

Note: Dependent variable is the yearly change in total immigrant employment in an education-experience cell as a percentage of initial immigrant employment in the cell; the explanatory variable is the change in new immigrant employment as a percentage of the initial immigrant employment. Each regression, weighted by the number of workers in the education-experience-period cell, includes education, experience and year fixed effects. Each observation point is an education-experience cell in a year. In parenthesis we report the heteroskedasticity-robust standard errors, clustered by education-experience group.

$* * *$ significantly different from 0 at the $1 \%$ level. 
Table 4

Estimates of $\rho$ : the employment effects of immigrants on natives

\begin{tabular}{|c|c|c|c|c|c|c|c|c|}
\hline Column & $\begin{array}{c}(1) \\
\text { Basic }\end{array}$ & $\begin{array}{c}(2) \\
\text { No Ethnic } \\
\text { Imputation }\end{array}$ & $\begin{array}{c}(3) \\
\text { Males and } \\
\text { Female }\end{array}$ & $\begin{array}{c}\text { (4) } \\
\text { Imputed } \\
\text { Equivalent } \\
\text { Education }\end{array}$ & $\begin{array}{c}\text { (5) } \\
1992-2001 \\
\text { subsample }\end{array}$ & $\begin{array}{c}(6) \\
1987-1999 \\
\text { sub- } \\
\text { sample } \\
\end{array}$ & $\begin{array}{c}(7) \\
2 S L S, \\
\text { Basic }\end{array}$ & $\begin{array}{c}(8) \\
\text { 2SLS, No } \\
\text { Ethnic } \\
\text { Imputation }\end{array}$ \\
\hline Estimates of $\rho$ & $\begin{array}{c}1.272^{* * *} \\
(0.384)\end{array}$ & $\begin{array}{c}1.327 * * * \\
(0.391)\end{array}$ & $\begin{array}{c}1.023^{* * *} \\
(0.520)\end{array}$ & $\begin{array}{c}1.358 * * * \\
(0.431)\end{array}$ & $\begin{array}{c}1.280^{* * *} \\
(0.530)\end{array}$ & $\begin{array}{c}1.207^{* * *} \\
(0.324)\end{array}$ & $\begin{array}{c}2.683^{* * *} \\
(1.015)\end{array}$ & $\begin{array}{c}2.819 * * * \\
(1.069)\end{array}$ \\
\hline T statistic & 3.310 & 3.393 & 1.967 & 3.151 & 2.416 & 3.728 & 2.640 & 2.640 \\
\hline $\begin{array}{l}\text { P-value: } \\
\mathrm{H}_{0}: \rho=1\end{array}$ & 0.487 & 0.412 & 0.965 & 0.415 & 0.603 & 0.529 & 0.097 & 0.089 \\
\hline Period & $1987-2001$ & $1987-2001$ & $1987-2001$ & $1987-2001$ & $1992-2001$ & 1987-1999 & 1992-2001 & 1992-2001 \\
\hline Group & Males & Males & $\begin{array}{l}\text { Males and } \\
\text { Females }\end{array}$ & Males & Males & Males & Males & Males \\
\hline Ethnics' imputation & Yes & No & Yes & Yes & Yes & Yes & Yes & No \\
\hline Equivalent education & No & No & No & Yes & No & No & No & No \\
\hline Observations & 359 & 359 & 359 & 359 & 240 & 311 & 238 & 238 \\
\hline \multicolumn{9}{|l|}{ First stage } \\
\hline East-West migrants & & & & & & & 1.29 & 1.23 \\
\hline Standard error & & & & & & & 0.17 & 0.17 \\
\hline T statistic & & & & & & & 7.58 & 7.34 \\
\hline F-test of exclusion & & & & & & & 57.38 & 53.91 \\
\hline
\end{tabular}

Note: Dependent variable is the yearly change in total employment in an education-experience cell as a percentage of the initial employment in the cell; the explanatory variable is the change in immigrant employment as a percentage of the initial employment. Each regression, weighted by the number of workers in the education-experience-period cell, includes education, experience and year fixed effects. In parenthesis we report the heteroskedasticity-robust standard errors, clustered by education-experience group.

$* * *, * *, *$ different from 0 at the $1 \%, 5 \%, 10 \%$ significance level. 
Table 5

Estimates of $1 / \lambda$, the inverse elasticity of substitution between new and long-term immigrants

\begin{tabular}{|c|c|c|c|c|c|c|c|c|c|}
\hline Column & $\begin{array}{c}(1) \\
\text { Basic }\end{array}$ & $\begin{array}{c}\text { (2) } \\
\text { No Ethnic } \\
\text { imputation }\end{array}$ & $\begin{array}{c}\text { (3) } \\
\text { Males and } \\
\text { Females }\end{array}$ & $\begin{array}{c}\text { (4) } \\
\text { Full time } \\
\text { workers } \\
\text { only }\end{array}$ & $\begin{array}{c}\text { (5) } \\
\text { Imputed } \\
\text { Equivalent } \\
\text { Education }\end{array}$ & $\begin{array}{c}(6) \\
\text { 1992-2001 } \\
\text { subsample }\end{array}$ & $\begin{array}{c}(7) \\
1987- \\
1999 \\
\text { subsample }\end{array}$ & $\begin{array}{c}(8) \\
\text { 2SLS basic }\end{array}$ & $\begin{array}{c}\text { (9) } \\
\text { 2SLS, no } \\
\text { ethnic } \\
\text { Imputation }\end{array}$ \\
\hline Estimation method & OLS & OLS & OLS & OLS & OLS & OLS & OLS & 2SLS & 2SLS \\
\hline $\begin{array}{c}\text { Estimate of } 1 / \lambda \\
\text { Period }\end{array}$ & $\begin{array}{c}0.017 \\
(0.011) \\
1987- \\
2001\end{array}$ & $\begin{array}{c}0.014 \\
(0.010) \\
1987-2001\end{array}$ & $\begin{array}{c}0.000 \\
(0.009) \\
1987-2001\end{array}$ & $\begin{array}{c}0.022 \\
(0.012) \\
1987- \\
2001\end{array}$ & $\begin{array}{c}0.004 \\
(0.010) \\
1987-2001\end{array}$ & $\begin{array}{c}0.017 \\
(0.010) \\
1992-2001\end{array}$ & $\begin{array}{c}0.010 \\
(0.010) \\
1987- \\
1999\end{array}$ & $\begin{array}{c}0.02 \\
(0.01) \\
1992-2001\end{array}$ & $\begin{array}{c}0.02 \\
(0.01) \\
1992-2001\end{array}$ \\
\hline Group & Males & Males & $\begin{array}{l}\text { Males and } \\
\text { Females }\end{array}$ & Males & Males & Males & Males & Males & Males \\
\hline Ethnics' imputation & Yes & No & Yes & Yes & Yes & Yes & Yes & Yes & No \\
\hline Equivalent education & No & No & No & No & Yes & No & No & No & No \\
\hline $\begin{array}{l}\text { Wages of FY work. } \\
\text { only }\end{array}$ & No & No & No & Yes & Yes & No & No & No & No \\
\hline Observations & 313 & 313 & 313 & 313 & 313 & 210 & 313 & 210 & 210 \\
\hline \multicolumn{10}{|l|}{ First stage } \\
\hline East-West migrants & & & & & & & & 0.66 & 0.67 \\
\hline Standard error & & & & & & & & 0.05 & 0.05 \\
\hline T statistic & & & & & & & & 12.10 & 13.85 \\
\hline F-test of exclusion & & & & & & & & 146.74 & 191.91 \\
\hline
\end{tabular}

Note: dependent variable is the relative new/old immigrant wages in an experience-education cell, explanatory variable is the relative new/old immigrant employment in the cell. Each regression, weighted by the number of workers in the education-experience-period cell, includes education, experience and year fixed effects. In parenthesis we report the heteroskedasticity-robust standard errors, clustered by education-experience group. $* * *, * *, *$ different from 0 at the $1 \%, 5 \%, 10 \%$ significance level. 
Table 6

Estimates of $1 / \sigma$, the inverse elasticity of substitution between immigrants and natives

\begin{tabular}{|c|c|c|c|c|c|c|c|c|c|}
\hline Column & $\begin{array}{c}(1) \\
\text { Basic }\end{array}$ & $\begin{array}{c}(2) \\
\text { No Ethnic } \\
\text { imputation }\end{array}$ & $\begin{array}{c}(3) \\
\text { Males } \\
\text { and } \\
\text { Females }\end{array}$ & $\begin{array}{c}(4) \\
\text { Full time } \\
\text { workers } \\
\text { only } \\
\end{array}$ & $\begin{array}{c}\text { (5) } \\
\text { Imputed } \\
\text { Equivalent } \\
\text { Education }\end{array}$ & $\begin{array}{c}(6) \\
1992- \\
2001 \\
\text { subsample }\end{array}$ & $\begin{array}{c}(7) \\
1987- \\
1999 \\
\text { subsample }\end{array}$ & $\begin{array}{c}(8) \\
2 \text { SLS } \\
\text { basic }\end{array}$ & $\begin{array}{c}(9) \\
\text { 2SLS, no } \\
\text { ethnic } \\
\text { Imputation }\end{array}$ \\
\hline Estimation method & OLS & OLS & OLS & OLS & OLS & OLS & OLS & IV & IV \\
\hline Estimates of $1 / \sigma$ & $\begin{array}{c}0.046 * * * \\
(0.011)\end{array}$ & $\begin{array}{c}0.046 * * * \\
(0.011)\end{array}$ & $\begin{array}{c}0.038 * * * \\
(0.011)\end{array}$ & $\begin{array}{c}0.035 * * * \\
(0.011)\end{array}$ & $\begin{array}{l}0.037^{*} \\
(0.020)\end{array}$ & $\begin{array}{l}0.029 * * \\
(0.013)\end{array}$ & $\begin{array}{c}0.060 * * * \\
(0.013)\end{array}$ & $\begin{array}{c}0.030 * * \\
(0.016) \\
\end{array}$ & $\begin{array}{c}0.030 * * \\
(0.015) \\
\end{array}$ \\
\hline Period & $\begin{array}{l}1987- \\
2001 \\
\end{array}$ & $\begin{array}{l}1987- \\
2001 \\
\end{array}$ & $\begin{array}{l}1987- \\
2001 \\
\end{array}$ & $\begin{array}{c}1987- \\
2001 \\
\end{array}$ & $\begin{array}{l}1987- \\
2001 \\
\end{array}$ & $\begin{array}{l}1992- \\
2001 \\
\end{array}$ & 1987-1999 & $\begin{array}{l}1992- \\
2001 \\
\end{array}$ & 1992-2001 \\
\hline Group & Males & Males & $\begin{array}{c}\text { Males } \\
\text { and } \\
\text { Females }\end{array}$ & Males & Males & Males & Males & Males & Males \\
\hline Ethnics' imputation & Yes & No & Yes & Yes & Yes & Yes & Yes & Yes & No \\
\hline Equivalent education & No & No & No & No & Yes & No & No & No & No \\
\hline $\begin{array}{l}\text { Wages of FY work. } \\
\text { only* }\end{array}$ & No & No & No & Yes & Yes & No & No & No & No \\
\hline Observations & 359 & 359 & 359 & 359 & 359 & 240 & 359 & 238 & 238 \\
\hline \multicolumn{10}{|l|}{ First stage } \\
\hline East-West migrants & & & & & & & & 0.80 & 0.80 \\
\hline Standard error & & & & & & & & 0.05 & 0.05 \\
\hline T statistic & & & & & & & & 16.24 & 17.29 \\
\hline F-test of exclusion & & & & & & & & 263.67 & 298.86 \\
\hline
\end{tabular}

Note: dependent variable is the relative native/immigrant wages in an experience-education cell; the explanatory variable is the relative

native/immigrant employment in the cell. Each regression, weighted by the number of workers in the education-experience-period cell, includes education, experience and year fixed effects. In parenthesis we report the heteroskedasticity-robust standard errors, clustered by educationexperience group.

$* * *, * *, *$ different from 0 at the $1 \%, 5 \%, 10 \%$ significance level. 
Table 7

Estimates of $1 / \eta$, the inverse of the elasticity of substitution between workers with different potential experience

\begin{tabular}{lcc}
\hline Column & $\begin{array}{c}(1) \\
\text { Using the model to } \\
\text { calculate }\left(\mathrm{L}_{\mathrm{kj}}\right) \text { as a CES } \\
\text { composite }\end{array}$ & $\begin{array}{c}\text { (2) } \\
\mathrm{L}_{\mathrm{kj}} \text { calculated as simple } \\
\text { employment counts }\end{array}$ \\
\hline Estimates of $1 / \eta$ & $\begin{array}{c}0.31^{* * *} \\
(0.11)\end{array}$ & $\begin{array}{c}0.33^{* * *} \\
(0.13)\end{array}$ \\
\hline T statistic & 2.69 & 2.50 \\
\hline Education trend & Yes & Yes \\
\hline Year Dummies & & Yes \\
\hline Experience Dummies & Yes & 359 \\
\hline Observations & 359 & \\
\hline
\end{tabular}

Note: Dependent variable is the average daily wage in real terms for the education-experience group. In column (1) the explanatory variable is $\log$ of $L_{\mathrm{kj}}$ obtained as a CES composite of natives and immigrants for a value of $1 / \sigma$ $=0.046$. In column (2) the explanatory variable is the log of the $L_{\mathrm{kj}}$ obtained as the simple sum of native and immigrant employment. The method of estimation used is 2SLS using as instrumental variable for $\ln \left(\mathrm{L}_{\mathrm{kj}}\right)$ the variable $\ln \left(\mathrm{M}_{\mathrm{kj}}\right)$, that is the log of immigrant employment in the cell. Standard errors are heteroskedasticity-robust clustered at the education-experience level. Regressions are weighted with the number of workers in each cell. $* * *, * *, *$ different from 0 at the $1 \%, 5 \%, 10 \%$ significance level. 
Table 8

Estimates of $1 / \delta$, the inverse of the elasticity of substitution between workers with different education levels

\begin{tabular}{lcc}
\hline Column & $(1)$ & $(2)$ \\
& Using the model to & $\mathrm{L}_{\mathrm{k}}$ calculated as \\
& calculate $\mathrm{L}_{\mathrm{k}}$ as a & simple employment \\
& CES composite & counts \\
\hline Estimates of $1 / \delta$ & $0.34^{* * *}$ & $0.37^{* * *}$ \\
& $(0.14)$ & $(0.16)$ \\
\hline Education trend & Yes & Yes \\
\hline Year Dummies & Yes & Yes \\
\hline Observations & 45 & 45 \\
\hline
\end{tabular}

Note: Dependent variable is the average daily wage in real terms for the education group. In column (1) the explanatory variable is $\log$ of $L_{k}$ obtained as a CES composite of different experience groups for a value of $1 / \eta$ $=0.31$. In column (2) the explanatory variable is the log of the $L_{k}$ obtained as the simple sum of employment across experience groups. The method of estimation is $2 \mathrm{SLS}$ using as instrumental variable for $\ln \left(\mathrm{L}_{\mathrm{k}}\right)$ the variable $\ln \left(\mathrm{M}_{\mathrm{k}}\right)$ that is the log of immigrant employment in the education cell. Standard errors are heteroskedasticity-robust clustered at the education-experience level. Regressions are weighted with the number of workers in each cell. $* * *, * *, *$ different from 0 at the $1 \%, 5 \%, 10 \%$ significance level. 
Table 9

Simulated long-run effects of immigration 1992-2001 on real wages of long-term immigrants (pre-1992)

\begin{tabular}{lccccccccc}
\hline Column & $(1)$ & $(2)$ & $(3)$ & $(4)$ & $(5)$ & $(6)$ & $(7)$ & $(8)$ & $(9)$ \\
\hline \multirow{2}{*}{ Education } & $\begin{array}{c}\text { Due to East-West movers } \\
\text { immigration } \\
\text { effect (A) }\end{array}$ & $\begin{array}{c}\text { Indirect } \\
\text { effect } \\
(\mathrm{B})\end{array}$ & $\begin{array}{c}\text { Total } \\
\text { effect } \\
\text { (A+B) }\end{array}$ & $\begin{array}{c}\text { Direct } \\
\text { immigration } \\
\text { effect (A) }\end{array}$ & $\begin{array}{c}\text { Indirect } \\
\text { effect } \\
\text { (B) }\end{array}$ & $\begin{array}{c}\text { Total } \\
\text { effect } \\
\text { (A+B) }\end{array}$ & $\begin{array}{c}\text { Direct } \\
\text { immigration } \\
\text { effect (A) }\end{array}$ & $\begin{array}{c}\text { Indirect } \\
\text { effect } \\
(\mathrm{B})\end{array}$ & $\begin{array}{c}\text { Total } \\
\text { effect } \\
(\mathrm{A}+\mathrm{B})\end{array}$ \\
\hline $\begin{array}{l}\text { No Vocational } \\
\text { Education }\end{array}$ & $0.17 \%$ & $-0.04 \%$ & $0.14 \%$ & $-1.63 \%$ & $0.79 \%$ & $-0.84 \%$ & $-1.46 \%$ & $0.76 \%$ & $-0.70 \%$ \\
\hline $\begin{array}{l}\text { Vocational } \\
\text { Education }\end{array}$ & $-0.54 \%$ & $0.37 \%$ & $-0.17 \%$ & $-0.34 \%$ & $0.32 \%$ & $-0.02 \%$ & $-0.88 \%$ & $0.69 \%$ & $-0.19 \%$ \\
\hline Higher Education & $-1.08 \%$ & $0.59 \%$ & $-0.49 \%$ & $-1.57 \%$ & $0.95 \%$ & $-0.62 \%$ & $-2.65 \%$ & $1.54 \%$ & $-1.11 \%$ \\
\hline Average & $-0.22 \%$ & $0.18 \%$ & $-0.04 \%$ & $-1.07 \%$ & $0.60 \%$ & $-0.47 \%$ & $-1.29 \%$ & $0.78 \%$ & $-0.51 \%$ \\
\hline
\end{tabular}

Note: Long-run simulations, assuming that capital adjusts over the period to keep the real return constant. The columns labeled "Direct immigration effects" show the real wage impact of a change in supply due to new immigrants, while those labeled "indirect effect" show the wage impact of the reduction in labor supply of old immigrants in response to new immigration.

Parameters used for the simulation: $\delta=2.9, \eta=3.3 ; \sigma=21.5 ; \lambda=58.1 ; \gamma=0.69$. 
Table 10

Simulated effects of immigration 1992-2001 on the real wage bills of long-term immigrants (pre 1992)

\begin{tabular}{lccc}
\hline \multirow{2}{*}{\multicolumn{1}{c}{ Education }} & $(1)$ & $(2)$ & $(3)$ \\
\cline { 2 - 4 } & $\begin{array}{c}\text { Due to East- } \\
\text { West movers }\end{array}$ & Due to foreigners & Total \\
\hline No Vocational Education & $-0.9 \%$ & $-10.1 \%$ & $-11.0 \%$ \\
\hline Vocational Education & $-9.7 \%$ & $-11.9 \%$ & $-21.6 \%$ \\
\hline Higher Education & $-14.4 \%$ & $-25.1 \%$ & $-39.5 \%$ \\
\hline Average & $-5.7 \%$ & $-11.9 \%$ & $-17.6 \%$ \\
\hline
\end{tabular}

Note: Long-run simulations, assuming that capital adjusts over the period to keep its real return constant. Parameters used for the simulation: $\delta=2.9, \eta=3.3 ; \sigma=21.5 ; \lambda=58.1 ; \gamma=0.69$. 
Table 11

Simulated effects of immigration 1992-2001 on real wages of native workers

\begin{tabular}{lcc}
\hline Column & $(1)$ & $(2)$ \\
\hline$\sigma$ & 21.5 & Infinite \\
\hline No Vocational Education & $1.68 \%$ & $1.85 \%$ \\
\hline Vocational Education & $-0.14 \%$ & $-0.25 \%$ \\
\hline Higher Education & $-1.01 \%$ & $-1.26 \%$ \\
\hline Average & $-0.02 \%$ & $-0.11 \%$ \\
\hline
\end{tabular}

Note: Long-run simulations, assuming that capital adjusts over the period to keep its real return constant. Parameters used for the simulation: $\delta=2.9, \eta=3.3 ; \lambda=58.1 ; \gamma=0.69$ 
Table 12

Estimated effects of new immigrants on natives and old immigrants, with displacement

\begin{tabular}{|c|c|c|c|c|c|}
\hline Column & (1) & (2) & (3) & $(4)=(1 * 2)$ & $(5)=(1 * 3)$ \\
\hline & $\begin{array}{l}\text { Number of } \\
\text { displaced } \\
\text { old } \\
\text { immigrants }\end{array}$ & $\begin{array}{l}\text { Cost for } \\
\text { unemployed } \\
\text { worker }\end{array}$ & $\begin{array}{l}\text { Average } \\
\text { yearly } \\
\text { wage }\end{array}$ & $\begin{array}{c}\text { Absolute } \\
\text { yearly cost of } \\
\text { unemployment } \\
\text { insurance }\end{array}$ & $\begin{array}{c}\text { Absolute } \\
\text { yearly wage } \\
\text { loss from } \\
\text { displacement }\end{array}$ \\
\hline $\begin{array}{l}\text { Unemployment insurance for displaced } \\
\text { workers } \\
\text { Foregone production }\end{array}$ & $\begin{array}{l}25,586 \\
25,586\end{array}$ & 14,449 & 25,996 & $369,694,682$ & $665,129,807$ \\
\hline
\end{tabular}

Note: Parameter used for the simulation of the employment effect: $\gamma=0.69$. 
Table 13

Policy experiment: redistributive effects

\begin{tabular}{|c|c|c|c|c|c|c|c|}
\hline \multirow[t]{3}{*}{ Column } & $(1)$ & $(2)$ & $(3)$ & $(4)=(2 * 3)$ & $(5=1 * 4)$ & $(6)$ & $(7)=(1 * 6)$ \\
\hline & \multirow{2}{*}{$\begin{array}{c}\text { Number of } \\
\text { employed } \\
\text { workers }\end{array}$} & \multirow{2}{*}{$\begin{array}{c}\text { Average } \\
\text { yearly } \\
\text { wage }\end{array}$} & \multicolumn{3}{|c|}{$\begin{array}{c}\text { Wage variations with no } \\
\text { displacement }\end{array}$} & \multicolumn{2}{|c|}{$\begin{array}{l}\text { Unemployment insurance } \\
\text { funding* }\end{array}$} \\
\hline & & & $\begin{array}{c}\text { Percentage } \\
\text { wage } \\
\text { variation }\end{array}$ & $\begin{array}{c}\text { Absolute } \\
\text { variation } \\
\text { in yearly } \\
\text { wage } \\
\end{array}$ & $\begin{array}{l}\text { Total yearly } \\
\text { variation }\end{array}$ & $\begin{array}{c}\text { Average } \\
\text { yearly cost } \\
\text { per } \\
\text { worker* }\end{array}$ & $\begin{array}{l}\text { Total yearly } \\
\text { cost* }^{*}\end{array}$ \\
\hline Total Natives & $8,519,550$ & 30,917 & $0.016 \%$ & 5.0 & $42,758,744$ & 38.0 & $324,023,685$ \\
\hline No vocational edu & $1,448,750$ & 18,993 & $-0.006 \%$ & -1.2 & $-1,708,739$ & 23.4 & $33,849,305$ \\
\hline Vocational education & $5,972,550$ & 31,619 & $0.031 \%$ & 9.8 & $58,333,987$ & 38.9 & $232,310,814$ \\
\hline Higher education & $1,098,250$ & 42,829 & $-0.029 \%$ & -12.6 & $-13,866,505$ & 52.7 & $57,863,566$ \\
\hline Total Old immigrants & $1,428,150$ & 25,996 & $-0.153 \%$ & -39.7 & $-56,633,145$ & 32.0 & $45,670,997$ \\
\hline No vocational edu & 573,700 & 22,310 & $-0.117 \%$ & -26.1 & $-14,951,133$ & 27.4 & $15,745,620$ \\
\hline Vocational education & 747,150 & 26,818 & $-0.124 \%$ & -33.1 & $-24,756,151$ & 33.0 & $24,649,383$ \\
\hline Higher education & 107,300 & 39,970 & $-0.395 \%$ & -157.7 & $-16,925,860$ & 49.2 & $5,275,994$ \\
\hline Total & $9,947,700$ & 30,210 & $-0.005 \%$ & -1.4 & $-13,874,401$ & 37.2 & $369,694,682$ \\
\hline
\end{tabular}

*The average yearly cost sustained by each type of worker to finance the unemployment insurance scheme assumed to be proportional to her wage.

Note: Parameters used for the simulations: $\delta=2.9, \eta=3.3 ; \sigma=21.5 ; \lambda=58.1 ; \gamma=0.69$. Employment is calculated as the total count of workers employed as of July $1^{\text {st }}$ of year 2000. Average daily wages are expressed in 2000 Euros. 
Figure 1

Immigrants as Share of total workers

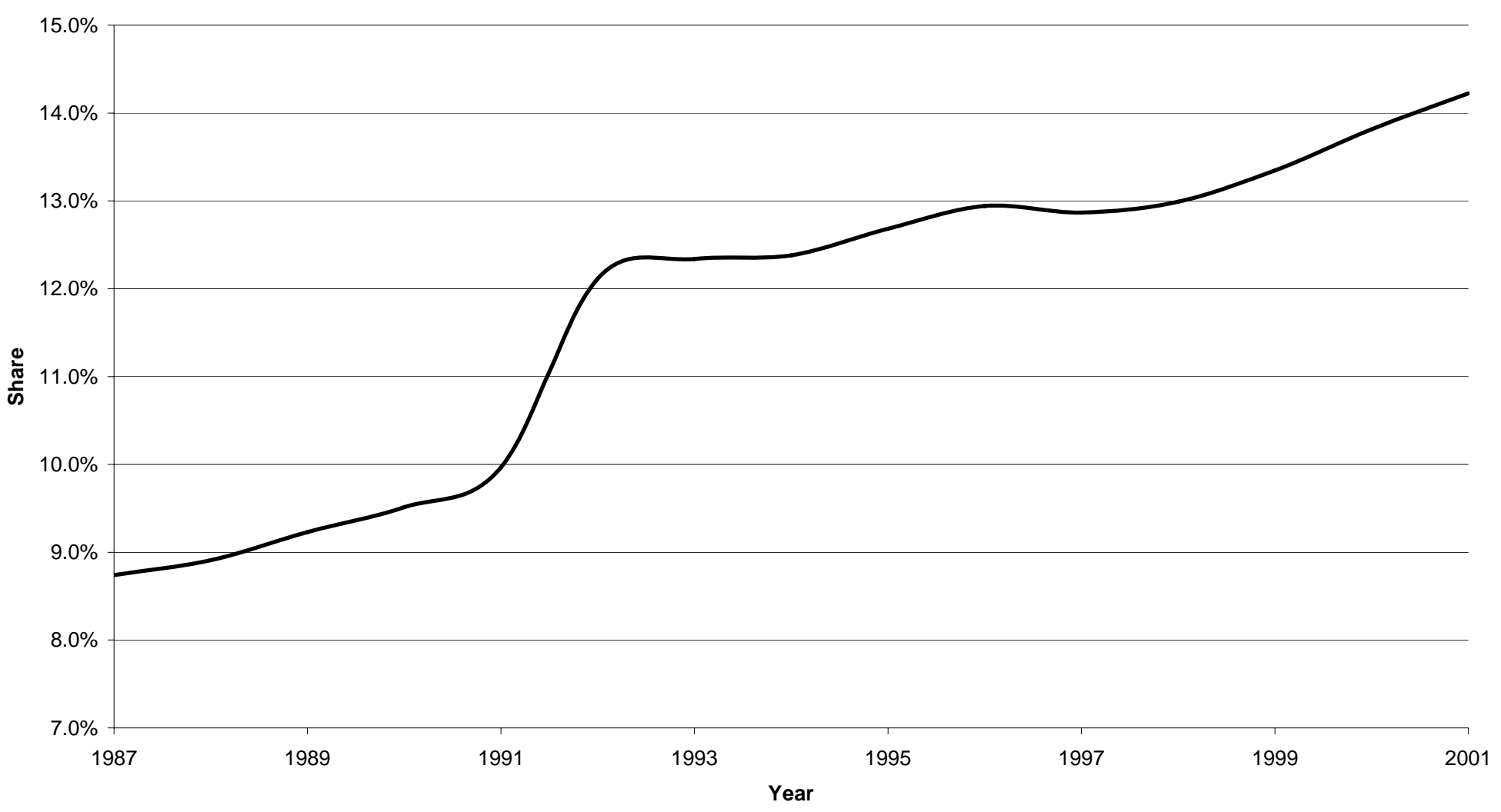

Source: Authors' calculations based on IAB data. Immigrants are the sum of foreign nationals plus workers who immigrated from Eastern Germany plus Ethnic Germans who immigrated from abroad. 


\section{Figure 2}

Unemployment Insurance recipients as share of labor the Labor Force

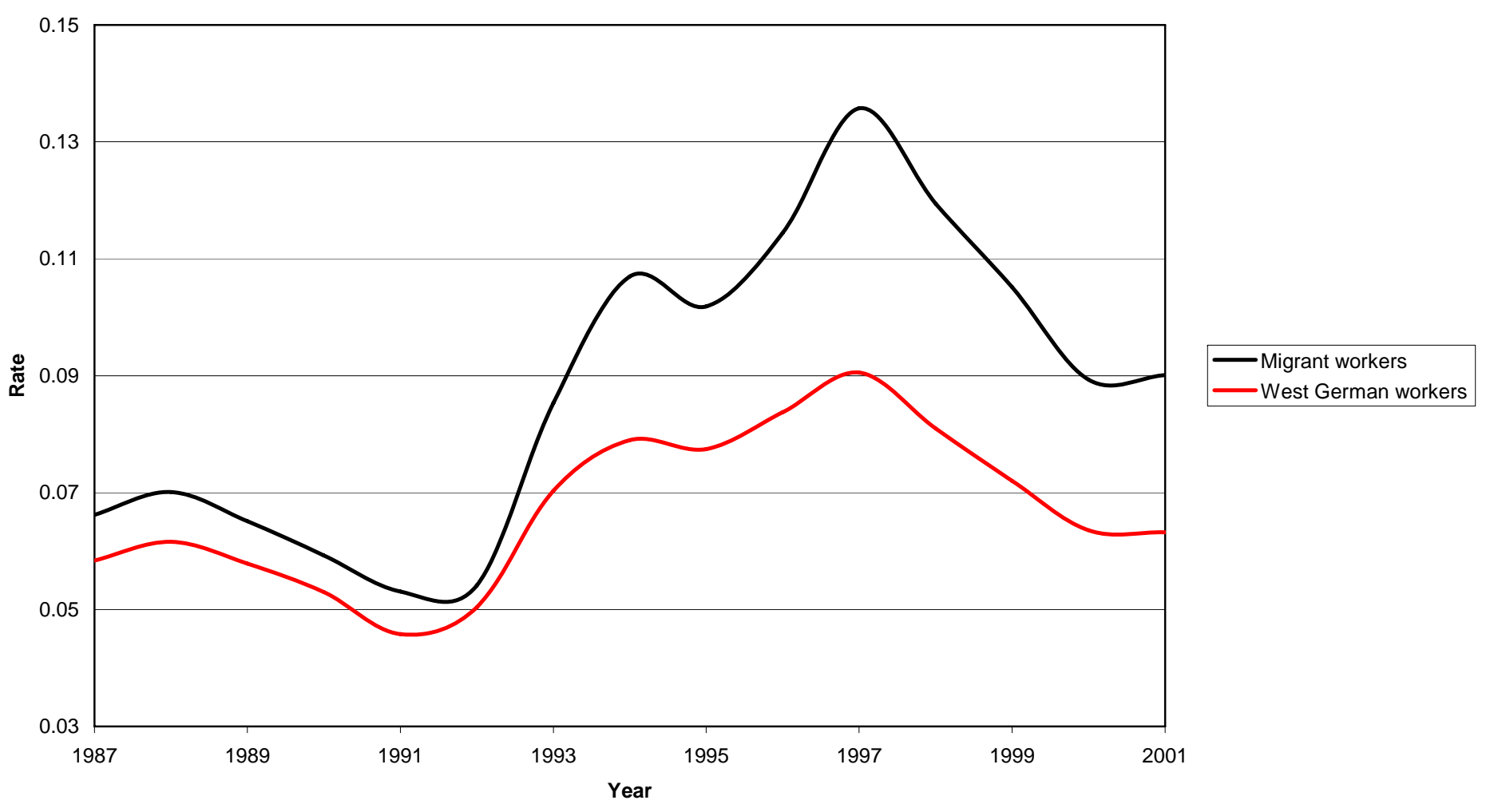

Source: Authors' calculations based on IAB data. The “Unemployment Insurance recipient rate” is equal to the share of individuals receiving unemployment benefits relative to the sum of workers and individuals receiving unemployment benefits. 